University of Michigan Law School

University of Michigan Law School Scholarship Repository

\title{
The Personal Responsibility Pandemic: Centering Solidarity in Public Health and Employment Law
}

\author{
Lindsay F. Wiley \\ Washington College of Law, wiley@wcl.american.edu \\ Samuel R. Bagenstos \\ University of Michigan Law School, sambagen@umich.edu
}

Available at: https://repository.law.umich.edu/articles/2209

Follow this and additional works at: https://repository.law.umich.edu/articles

Part of the Health Law and Policy Commons, Labor and Employment Law Commons, and the Law and Society Commons

\section{Recommended Citation}

Wiley, Lindsay F and Samuel Bagenstos. "The Personal Responsibility Pandemic: Centering Solidarity in Public Health and Employment Law." Ariz. St. L. J. 52 (2020): 1235-1302.

This Article is brought to you for free and open access by the Faculty Scholarship at University of Michigan Law School Scholarship Repository. It has been accepted for inclusion in Articles by an authorized administrator of University of Michigan Law School Scholarship Repository. For more information, please contact mlaw.repository@umich.edu. 


\title{
The Personal Responsibility Pandemic: Centering Solidarity in Public Health and Employment Law
}

\author{
Lindsay F. Wiley* and Samuel R. Bagenstos ${ }^{* *}$
}

\section{INTRODUCTION}

Our nation's response to the coronavirus pandemic has revealed fundamental flaws in our legal regimes governing both public health and employment. Public health orders have called on individuals to make sacrifices to protect society as a whole. Simple fairness dictates that the burdens should be shared as widely as the benefits. And the case for burdensharing does not rest on fairness alone. Public health measures are more likely to succeed when those who are subject to them understand them as fair ${ }^{1}$ and when their cooperation is supported. ${ }^{2}$ Predictably, our pandemic response has placed disproportionate burdens on those who are already disadvantaged due to economic, racial, gender, disability, immigration, and criminal injustice. ${ }^{3}$ Elected officials have asked each of us to take personal responsibility for weathering this crisis rather than providing community supports and legal

\footnotetext{
* Professor of Law and Director of the Health Law and Policy Program, American University Washington College of Law.

** Frank G. Millard Professor of Law, University of Michigan Law School. Thanks to Julianna St. Onge for able research assistance.

1. See Bellagio GrP., Bellagio Statement of Principles 1, https://www.unicef.org/avianflu/files/Bellagio_Statement.pdf [https://perma.cc/5DN9-EXZT]

("Consideration for the interests of the disadvantaged is important for practical as well as ethical reasons: public health efforts [to respond to a pandemic] are more likely to succeed in an atmosphere of social solidarity and public trust, including the trust of disadvantaged people.").

2. See, e.g., Nancy M. Baum, Peter D. Jacobson \& Susan D. Goold, "Listen to the People”: Public Deliberation About Social Distancing Measures in a Pandemic, 9 AM. J. Bioethics 4, 11 (2009) ("Policy makers must address [economic] concerns to effectively implement and sustain social distancing measures during a pandemic."); Amitai Etzioni, Public Health Law: A Communitarian Perspective, 21 HeALTH AFFs. 102, 104 (2002) ("[U]nfair allocation of [the burdens of public health policies] would undermine the legitimacy, and hence sustainability, of [measures to respond to a public health crisis]. . . . [M] uch more discussion is called for about how to minimize the extra weight that inevitably will fall on some people [as a result of public health policies that curtail movements, work, and trade] such as how to possibly compensate them for such burdens if they cannot be avoided ....").

3. See Bellagio GrP., supra note 1 ("Socially and economically disadvantaged groups and individuals are almost always the worst affected by epidemics.").
} 
protections that would cushion the blow, spread the costs more widely, and enable everyone to abide by and benefit from public health recommendations.

The failed U.S. response to the coronavirus pandemic has resulted in significant part from limitations in the moral vision of our employment and antidiscrimination laws. Tens of millions of Americans have filed for unemployment. ${ }^{4}$ Supplemental benefits have been meager and time-limited. ${ }^{5}$ Many low-wage workers - who are disproportionately people of color, immigrants, and women ${ }^{6}$ - have been exposed to high risk of infection, blamed for outbreaks, punished for refusing to return to unsafe working conditions, and framed as separate from "the regular folks" in our communities. $^{7}$

This article offers a critique of the U.S. pandemic response as well as concrete proposals for reform. Normatively, our argument is rooted in a solidarity-based theory of public health. The essential point of that theory is this: Infectious disease pandemics are fueled by the connection of people to one another in society. The same human interconnectedness demands prevention and response measures grounded in mutual aid. Public health has been described as "what we, as a society, do collectively to assure the conditions in which people can be healthy." 8 The public health ethicists whose work informs our proposals identify solidarity (interdependence

\footnotetext{
4. Scott Horsley, 38.6 Million Have Filed for Unemployment Since March, NPR (May 21, 2020, $8: 36 \quad \mathrm{AM}), \quad \mathrm{https} / /$ www.npr.org/sections/coronavirus-liveupdates/2020/05/21/859836248/38-6-million-have-filed-for-unemployment-since-march [https://perma.cc/K4KZ-5GL2].

5. See discussion infra Part II.B.2.

6. See Martha Ross \& Nicole Bateman, Metro. Pol'y Program, Meet the LowWAGE WORKFORCE 9 (2019), https://www.brookings.edu/wpcontent/uploads/2019/11/201911_Brookings-Metro_low-wage-workforce_Ross-Bateman.pdf [https://perma.cc/U24P-QQEJ]; Press Release, Bureau of Lab. Stat., U.S. Dep't of Lab., ForeignBorn Workers: Labor Force Characteristics-2019, at 1 (May 15, 2020), https://www.bls.gov/news.release/pdf/forbrn.pdf [https://perma.cc/FX5E-Y4AZ].

7. Meagan Flynn, Wisconsin Chief Justice Sparks Backlash by Saying Covid-19 Outbreak Is Among Meatpacking Workers, Not 'The Regular Folks, 'WASH. Post (May 7, 2020, 4:57 AM), https://www.washingtonpost.com/nation/2020/05/07/meatpacking-workers-wisconsincoronavirus/ [https://perma.cc/GKS3-8YTP] (describing Wisconsin Chief Judge Patience Roggensack's comment during oral argument attributing an outbreak in a rural county to meatpacking plant workers and distinguishing them from "the regular folks in Brown County"); see also Sick Staff Fueled Outbreak in Seattle-Area Nursing Homes, CDC Reports, NBC NEWS (Mar. 18, 2020, 1:02 PM), https://www.nbcnews.com/health/health-news/sick-staff-fueledoutbreak-seattle-nursing-homes-cdc-reports-n1163236 [https://perma.cc/FU9W-34E3].

8. Comm. For the Study of the Future of Pub. Health, Inst. of Med., The Future OF PUBLiC HEALTh 1 (1988).
} 
among individuals and groups), ${ }^{9}$ mutual aid (reciprocity of support), ${ }^{10}$ and communitarianism (connectedness between individuals and their communities) ${ }^{11}$ as important foundations for public health theory, science, practice, and law. Public health emergency prevention and response measures are meant to benefit society as a whole. The burdens should also be shared.

The coronavirus pandemic, like other public health crises before it, has demonstrated that the solidarity vision of public health is still largely aspirational. In the early days of the pandemic, some called it a "great equalizer." 12 But within a matter of weeks it became clear that the virus thrived on socioeconomic injustice, ableism, and structural racism. Reports attributed the first major outbreak of coronavirus disease 2019 (COVID-19) in the United States at the Life Care Center nursing home in Kirkland, Washington, to staff members who "worked with symptoms, worked in more than one facility, and sometimes didn't know about or follow recommendations about ... being careful while in close contact with ill patients." 13 Commentators noted, however, that nursing home jobs provide

9. See, e.g., Ryan M. Melnychuk \& Nuala P. Kenny, Pandemic Triage: The Ethical Challenge, 175 CAN. MED. ASS'N J. 1393, 1394 (2006) (noting that "solidarity (we are all in this together, and protecting the public and hence ourselves will require society-wide collaborations)" is highly relevant to pandemic planning); Françoise Baylis, Nuala P. Kenny \& Susan Sherwin, $A$ Relational Account of Public Health Ethics, 1 PuB. HeAlth ETHICs 196, 198 (2008) ("[I] ssues of trust, neighborliness, reciprocity and solidarity must be made central" to public health ethics.); Angus Dawson \& Bruce Jennings, The Place of Solidarity in Public Health Ethics, 34 PuB. HEALTH REVS. 65, 76-77 (2012) ("[S]olidarity is and ought to be at the heart of ethical thinking about public health. It does not only come into existence or prove relevant at times of grave 'threats' to a nation state, such as when a major pandemic hits the population.").

10. See, e.g., Bruce Jennings, Relational Liberty Revisited: Membership, Solidarity and a Public Health Ethics of Place, 8 PuB. HeAlth ETHics 7, 7 (2015) ("[B]oth the practical success of public health policies and programs and their capacity to gain normative legitimacy and trust rely on the presence of a cultural sense of obligation and mutual aid in a world of common vulnerability.").

11. See, e.g., Dan E. Beauchamp, Community: The Neglected Tradition of Public Health, 15 HASTINGS CTR. REP. 28, 34 (1985) ("By ignoring the communitarian language of public health, we risk shrinking its claims. We also risk undermining the sense in which health and safety are a signal commitment of the common life - a central practice by which the body-politic defines itself and affirms its values."); Etzioni, supra note 2, at 102.

12. See, e.g., Tim Molloy, Madonna's COVID-19 Bathtub Message: 'It's the Great Equalizer,' SPIN (Mar. 22, 2020, 4:05 PM), https://www.spin.com/2020/03/madonnas-covid-19bathtub-message-its-the-great-equalizer/ [https://perma.cc/H86B-WDE8]; Bethany L. Jones \& Jonathan S. Jones, Gov. Cuomo Is Wrong, Covid-19 Is Anything but an Equalizer, WASH. PosT (Apr. 5, 2020, 3:00 AM), https://www.washingtonpost.com/outlook/2020/04/05/gov-cuomo-iswrong-covid-19-is-anything-an-equalizer/ [https://perma.cc/4UNP-JXJA].

13. NBC News, supra note 7; see Temet M. McMichael et al., COVID-19 in a Long-Term Care Facility-King County, Washington, February 27-March 9, 2020, 69 CDC MORBIDITY \& $\begin{array}{lllll}\text { MORTALITY } & \text { WKLY. } & \text { REP. } & 339, & \text { (2020), }\end{array}$ 
low wages and don't offer paid sick leave, encouraging workers-who are overwhelmingly women of color ${ }^{14}$ - to work two or more jobs and continue to report for duty even when they're infected and might spread the virus to vulnerable residents. ${ }^{15}$ Outbreaks in other settings-including meat processing plants, jails, prisons, and detention centers ${ }^{16}$ - similarly implicated structural racism and weak legal protections for workers and people living in congregate facilities and government custody. ${ }^{17}$ The harm of these outbreaks fell especially heavily on immigrants and people of color. Early warnings from experts were rapidly borne out by overwhelming evidence that Black people, Indigenous people, Latinos, Latinas, and people with low socioeconomic status were contracting the virus and dying from it at sharply disproportionate rates. ${ }^{18} \mathrm{~A}$ combination of higher levels of workrelated and residential exposure to the virus and higher rates of the chronic cardiovascular and lung diseases that predispose individuals to severe illness and death from COVID-19 appeared to be key contributors. ${ }^{19}$

https://www.cdc.gov/mmwr/volumes/69/wr/pdfs/mm6912-H.pdf [ [https://perma.cc/RT3LBR2B].

14. Kezia Scales, PHI, It's Time To Care: A Detailed Profile of America's Direct CARE WORKFORCE 11-12 (2020), https://phinational.org/wp-content/uploads/2020/01/Its-Timeto-Care-2020-PHI.pdf [https://perma.cc/3QSR-4PZM] (showing that $86 \%$ of direct care workers are women, and $59 \%$ of direct care workers are people of color).

15. See NBC NEWS, supra note 7 (referencing Professor Charlene Harrington's, University of California, San Francisco School of Nursing, comments on nursing home workers).

16. See, e.g., Michelle A. Waltenburg et al., Update: COVID-19 Among Workers in Meat and Poultry Processing Facilities-United States, April-May 2020, 69 CDC MORBIDITY \& $\begin{array}{lllll}\text { MORTALITY WKLY. } & \text { REP. } & 887, & 887 & \text { (2020), }\end{array}$ https://www.cdc.gov/mmwr/volumes/69/wr/pdfs/mm6927-H.pdf [https://perma.cc/J9GHMQ8G]; Megan Wallace et al., COVID-19 in Correctional and Detention Facilities-United States, February-April 2020, 69 CDC Morbidity \& MorTality WKLy. ReP. 587, 587 (2020), https:/www.cdc.gov/mmwr/volumes/69/wr/pdfs/mm6919e1-H.pdf [https://perma.cc/F99DQ4BA].

17. See, e.g., Ruqaiijah Yearby \& Seema Mohapatra, Structural Discrimination in COVID19 Workplace Protections, HealthAfFairs.: Health AfFs. Blog (May 29, 2020), https://www.healthaffairs.org/do/10.1377/hblog20200522.280105/full/ [https://perma.cc/DZU87M6W]; Komala Ramachandra, US Meatpacking Workers Face Crisis, Slashed Safety Protections During Pandemic, HuM. RTS. WATCH (Apr. 24, 2020, 12:00 PM), https://www.hrw.org/news/2020/04/24/us-meatpacking-workers-face-crisis-slashed-safetyprotections-during-pandemic\# [https://perma.cc/KE46-KELQ]; Donald M. Berwick, Leanne Gale, Faith Barksdale \& Megan Hauptman, Protecting Incarcerated People in the Face of COVID-19: A Health and Human Rights Perspective, Healthaffairs: Health Affs. Blog (May 1, 2020), https://www.healthaffairs.org/do/10.1377/hblog20200428.846534/full/ [https://perma.cc/D4NE-MUG2].

18. See infra Part I.B.

19. See infra Part I.B. 
For centuries, public health advocates have understood that the spread of infection is affected by the conditions in which people live and work, ${ }^{20}$ conditions public health researchers now study as the social determinants of health..$^{21}$ But public health efforts to prevent and respond to the coronavirus pandemic in the United States have largely failed to address the conditions that influence exposure to infection in the workplace and in the crowded homes many low-wage workers share with others who are particularly vulnerable to COVID-19. ${ }^{22}$ Interventions targeting individuals for behavior change (wearing face masks, avoiding gatherings, staying home, and seeking out testing and separating from other household members based on symptoms or exposure) have taken precedence over social supports (provision of protective equipment and supplies, paid sick and family leave, accommodations for people with conditions that make them particularly vulnerable to severe illness or death, income support, easy access to testing, and privacy and antidiscrimination protections for those who may test positive). ${ }^{23}$ The supports aimed at ensuring the conditions required for everyone to be able to comply with public health recommendations have been spotty and inconsistent. ${ }^{24}$

20. See generally John Duffy, The SANitARIANS: A History OF AMERICAN PubliC HEAlth (1992). One of us has previously argued that the new public health in some ways represents a return to the commitments of the nineteenth-century Sanitarians who sought to improve living and working conditions, particularly for low-wage workers and people living in poverty. Lindsay F. Wiley, Rethinking the New Public Health, 69 WASH. \& LEE L. REV. 207, 228 (2012); see also Niyi Awofeso, What's New About the "New Public Health”?, 94 AM. J. PUB. HEALTH 705, 708 (2004).

21. See, e.g., Scott Burris, From Health Care Law to the Social Determinants of Health: A Public Health Law Research Perspective, 159 U. PA. L. REV. 1649 (2011); Michael G. Marmot, Understanding Social Inequalities in Health, 46 Persps. BIOlOGY \& Med. S9 (2003); COMM'N on Soc. Determinants of Health, World Health Org., Closing the GaP in a Generation: Health Equity Through Action on the Social Determinants of Health (2008), https://www.who.int/social_determinants/final_report/csdh_finalreport_2008.pdf [https://perma.cc/CZB3-KH9U].

22. See Marisol Cuellar Mejia \& Paulette Cha, Overcrowded Housing and COVID-19 Risk Among Essential Workers, PUB. POL'Y INST. OF CAL. (May 12, 2020), https:/www.ppic.org/blog/overcrowded-housing-and-covid-19-risk-among-essential-workers/ [https://perma.cc/HJ5E-VPLK].

23. Louis Bezich, Americans' Response to the Coronavirus Provides a Model for Future Behavior Change, PHILly VOICE (Apr. 7, 2020), https://www.phillyvoice.com/americancoronavirus-response-model-future-behavior-change-covid-19/ [https://perma.cc/H8FH-JD6F] ("[T] he U.S. response to COVID-19, albeit by necessity, is anchored in behavioral change ....").

24. See Emily A. Benfer \& Lindsay F. Wiley, Health Justice Strategies To Combat COVID19: Protecting Vulnerable Communities During a Pandemic, HealthAfFaIRs: Health Affs. BLOG (Mar. 19, 2020), https://www.healthaffairs.org/do/10.1377/hblog20200319.757883/full/ [https://perma.cc/AF8X-XFM5]. 
Law itself is a social determinant of health. ${ }^{25}$ As we show, a large part of the problem rests in the orientation of employment and antidiscrimination law toward identifying the fault and responsibility of private actors rather than serving broader social goals. ${ }^{26}$

Tension between a sweeping public health agenda that targets socioeconomic circumstances and a more cramped vision that relies on personal responsibility predates the coronavirus pandemic. It arises from competing models of public health problem-solving. ${ }^{27}$ "The tension between these models has shaped responses to earlier threats, including the HIV pandemic, tobacco- and diet-related illness, and substance abuse." ${ }^{28}$ The

25. See Scott Burris, Ichiro Kawachi \& Austin Sarat, Integrating Law and Social Epidemiology, 30 J.L. MED. \& ETHICs 510, 510 (2002) ("[L]aw [should be studied] as a social factor in epidemiological research . . . Laws and legal practices contribute to the development, and influence the stability, of social conditions that have been associated with population health outcomes $[, \ldots$ and] law operates as a pathway along which broader social determinants of health have an effect ...."). Some scholars refer to law as a structural determinant of health. See, e.g., Zita Lazzarini, Assessing the Public Health Response During and After the Emergency: Lessons from the HIV Epidemic, 4 St. Louis U. J. HEALTH L. \& POL'Y 187, 210-11 (2010); Seema Mohapatra, Unshackling Addiction: A Public Health Approach to Drug Use During Pregnancy, 26 WIS. J.L. GENDER \& SOC'Y 241, 261 (2011); Medha D. Makhlouf, The Public Charge Rule as Public Health Policy, 16 Ind. HeAlth L. ReV. 177, 196 (2019); Aila Hoss, Federal Indian Law as a Structural Determinant of Health, 47 J.L. MED. \& ETHICS S34 (2019). They are not wrong. Structural determinants are a subset of social determinants of health. The World Health Organization Commission on the Social Determinants of Health "has purposely adopted a broad initial definition of the social determinants of health," which "encompasses the full set of social conditions in which people live and work" including both the "structural determinants of health inequities" and "the more immediate determinants of individual health." ORIELLE SOLAR \& ALEC Irwin, World Health Org., A Conceptual Framework for Action on the Social $\begin{array}{lllll}\text { DETERMINANTS HEALTH } & \text { OF } & 9 & \text { (2010), }\end{array}$ https:/www.who.int/sdhconference/resources/ConceptualframeworkforactiononSDH_eng.pdf [https://perma.cc/AT3W-JKSU]. The structural determinants of health inequities include "social and political mechanisms that generate, configure and maintain social hierarchies," while the more immediate determinants of individual health include "material circumstances; psychosocial circumstances; behavioral and/or biological factors; and the health system itself." Id. at 5-6. Health-care providers seeking to provide limited support for the material needs of individual patients (e.g., housing stability, utilities, and transportation) in response to outcome-based reimbursement models have increasingly coopted the term social determinants of health, prompting some public health advocates to prefer more distinct labels, such as structural determinants or political determinants to describe law, policy, and economic and social conditions such as structural racism. See generally Lindsay F. Wiley, The Struggle for the Soul of Public Health, 41 J. HeAlth POL. POL'Y \& L. 1083 (2016). We use the original term, describing law and solidarity as social determinants of health, in an effort to reclaim its original, broader meaning.

26. See infra Part II.

27. See Wiley, supra note 20, at 227.

28. Lindsay F. Wiley, Structural Racism, Social Determinants, and the Contested Scope of Public Health Law, HARV. L. Petrie-Flom CTR. Blog (Sept. 29, 2020), 
"old" public health law of communicable disease control is "concerned with such undertakings as compulsory vaccination and treatment, isolation and quarantine, and disease surveillance." ${ }^{29}$ It was built on the microbial and behavioral models of public health. The microbial model "focuses on medical countermeasures to attack the pathogen" while the behavioral model focuses on "altering the behavior of individual 'hosts' to reduce their susceptibility to disease and the risks they pose to others." 30

"In contrast, the 'new' public health seeks 'to expand communal provision' and address structural racism and other forms of social subordination." 31 This approach responds to the insights of social epidemiology 32 - the study of how social, economic, environmental, and cultural factors shape patterns of morbidity and mortality. ${ }^{33}$ Proponents of the new public health adopt a social-ecological model. ${ }^{34}$ They "search for defects in the community and the environment rather than in the individual; . . . to

https://blog.petrieflom.law.harvard.edu/2020/09/29/structural-racism-social-determinantshealth-law/ [https://perma.cc/WXQ8-FT6L]; see also LAWRENCE O. GOSTIN \& LiNDSAY F. Wiley, Public Health Law: Power, Duty, Restraint 20-26 (3d ed. 2016) (describing evolving models of public health problem solving and their influence on "old" and "new" public health law).

29. See Gostin \& WILEY, supra note 28 , at 20.

30. Wiley, supra note 28; see also GOSTIN \& WILEY, supra note 28, at 21-23 (describing the agent - also known as microbial — and behavioral models of public health problem solving).

31. Wiley, supra note 28 (first quoting DAN E. BEAUCHAMP, THE HEALTH OF THE REPUBLIC: Epidemics, Medicine, And Moralism as Challenges to Democracy 204 (1988); and then citing Angela P. Harris \& Aysha Pamukcu, The Civil Rights of Health: A New Approach to Challenging Structural Inequality, 66 UCLA L. REV. 758, 762 n.4, 810 (2020) (arguing that health disparities cannot be adequately addressed by strategies that fail to account for how structural inequalities created by subordination, "a set of policies, practices, traditions, norms, definitions, cultural stories, and explanations that function to systematically hold down one social group to the benefit of another social group" based on markers of social stigma such as race, gender, sexuality, and class (quoting Robin DiAngelo, What Does It Mean To Be White? DeVeloping White Racial Literacy 61 (Shirley R. Steinberg ed., 2012)))).

32. See Burris, supra note 21, at 1654 ("Responding to the findings of . . . social epidemiology is perhaps the true 'grand challenge' of our time in public health.").

33. See generally Social EPIDEMIOLOGY (Lisa F. Berkman, Ichiro Kawachi \& M. Maria Glymour eds., 2d ed. 2014) (explaining social epidemiology); NANCY KRIEGER, EPIDEMIOLOGY AND THE PEOPLE'S HEALTH: THEORY AND CONTEXT 163 (2011) (describing social epidemiology as an "alternative to biomedical and lifestyle theorizing about disease distribution"). Social epidemiology and the social determinants of health have deep implications for solidarity as a foundation of public health. Solidarity, like law, is a social determinant of health. See Dawson \& Jennings, supra note 9, at 77 ("[T] he structural conditions that undermine (or sustain) solidarity among social groups are related to key indicators of health and well-being.").

34. GOSTIN \& WILEY, supra note 28, at 381 (discussing the application of the socialecological model of public health to communicable disease prevention and control); see also; Awofeso, supra note 20, at 707 (discussing the application of "new public health" to develop a "more humane and less stigmatizing" approach to quarantine). See generally KRIEGER, supra note 33. 
see social problems, in a word, as social." 35 The behavioral model supports an ethos of personal responsibility for health; the social-ecological model demands a more community-minded approach. ${ }^{36}$

Critics of "an expansive public health philosophy grounded in fundamental socioeconomic and cultural transformation" argue that it pushes too hard against the traditional boundaries of public health practice, policy, and law. ${ }^{37}$ The new public health movement has been characterized as a threat to individual freedoms ${ }^{38}$ and to the coherence and neutrality of public health as a field. ${ }^{39}$ But the coronavirus pandemic, we argue, shows why a social focus is essential to achieving individual freedom as well as community solidarity.

Critical analysis of public health ethics, practice, law, and policy typically assumes a dichotomy between solidarity and individual freedom. ${ }^{40}$ But our experience with the coronavirus pandemic - much like our experience with the HIV pandemic ${ }^{41}$ — suggests this dichotomy isn't always so clear. Liberty

35. BEAUCHAMP, supra note 31, at 204 (quoting WILLIAM RYAN, BLAMING THE VICTIM 1516 (1st ed. 1971)); Wiley, supra note 28.

36. Wiley, supra note 20, at 227; see also Lawrence O. Gostin, Scott Burris \& Zita Lazzarini, The Law and the Public's Health: A Study of Infectious Disease Law in the United States, 99 COLUM. L. REV. 59, 72 (1999) ("[S] eeing public health predominantly as the control of risky behavior can quickly become, for cultural and political reasons, a warrant for treating health entirely as a matter of personal responsibility."); SOLAR \& IRWIN, supra note 25, at 4 ("Having health framed as a social phenomenon emphasizes health as a topic of social justice more broadly.").

37. Lawrence O. Gostin, Jo Ivey Boufford \& Rose Marie Martinez, The Future of the Public's Health: Vision, Values, and Strategies, 23 Health AfFs. 96, 96 (2004).

38. See, e.g., Mark. A. Rothstein, Rethinking the Meaning of Public Health, 30 J.L. MED. \& ETHICS 144, 148 (2002) [hereinafter Rothstein, Rethinking the Meaning of Public Health]; Richard A. Epstein, Let the Shoemaker Stick to His Last: A Defense of the "Old" Public Health, 46 Persps. Biology \& Med. S138, S139 (2003); Mark A. Hall, The Scope and Limits of Public Health Law, 46 PersPs. Biology \& MED. S199, S203 (2003); Mark A. Rothstein, The Limits of Public Health: A Response, 2 PuB. HeAlth Ethics 84, 85 (2009) [hereinafter Rothstein, The Limits of Public Health].

39. See, e.g., Lawrence O. Gostin, Public Health, Ethics, and Human Rights: A Tribute to the Late Jonathan Mann, 29 J.L. MED. \& ETHICS 121, 123 (2001); Rothstein, Rethinking the Meaning of Public Health, supra note 38, at 147; Hall, supra note 38, at S205; LAWRENCE O. Gostin, Public Health Law: Power, Duty, Restraint 41 (2d. ed. 2008); Rothstein, The Limits of Public Health, supra note 38 , at 85.

40. See, e.g., Dawson \& Jennings, supra note 9, at 71 ("[S]olidarity with fellow citizens is not as important to Americans as being able to chart the course of their own individual [destinies]" (quoting Rosemarie Tong, Shaping Ethical Guidelines for an Influenza Pandemic, in International Public Health Policy And Ethics 215, 219 (Michael Boylan ed., 2008)).

41. BEAUCHAMP, supra note 31, at 202 ("The most common misreading [of the ethical and moral issues that loom over the AIDS epidemic] is that the conflict is between the ethos of public health and that of civil liberty."); see also Scott Burris, Law and the Social Risk of Health Care: 
includes a worker's freedom to adopt protective public health practices without fear of adverse employment consequences. Solidarity can be libertypromoting in the face of a public health crisis with potential for enormous social, economic, and cultural disruption. Moreover, the pandemic has provided horrifying evidence that when public health interventions depend on individual behavior change while disregarding the social determinants that constrain individuals' choices, they are ineffective and unjust.

This article argues that effective pandemic prevention and response demands an approach rooted in solidarity, which in turn requires employment and antidiscrimination reforms to enable everyone to follow public health guidance for the protection of themselves and others. Our analysis emphasizes some features that are unique to how SARS-CoV-2, the virus that causes COVID-19, is transmitted. But our proposals also draw on experience with past pandemics - especially HIV — and are relevant to prevention of and response to future pandemics for which vaccines and therapeutics may be inadequate. When health officials rely on community mitigation strategies to slow the spread of infection, their urgent calls for individuals to change their behaviors must be accompanied by supports, accommodations, and legal protections. Otherwise, their efforts may exacerbate, rather than ameliorate, injustice, and their efficacy will be limited.

We make our argument in three parts. In Part I, we describe the community mitigation strategies adopted to slow the spread of the coronavirus pandemic. These strategies have relied heavily on requiring individuals to change their behavior. They include isolation of infected individuals and quarantine of their exposed contacts, social distancing to reduce contacts among the general population, infection control protocols, and shielding for people who are particularly vulnerable to COVID $-19 .{ }^{42}$ The result has been to cause severe COVID-19 illness and mortality - and the economic devastation that have accompanied it - to be disproportionately concentrated among socially subordinated groups. ${ }^{43}$ The benefits and burdens of public health responses to the coronavirus pandemic have been unjustly distributed in ways that exacerbate social fragmentation. ${ }^{44}$ Restrictions on public services and private

Lessons from HIV Testing, 61 ALB. L. REV. 831, 835-36 (1998) (arguing that individual rights to privacy and nondiscrimination in employment, housing, and public accommodations support HIV prevention goals).

42. See Lindsay F. Wiley, Democratizing the Law of Social Distancing, 19 YALE J. HeALTH POL'Y L. \& ETHICS 50 (2020).

43. See infra Part I.B.

44. See, e.g., Max Fisher \& Emma Bubola, As Coronavirus Deepens Inequality, Inequality Worsens Its Spread, N.Y. TIMES (Mar. 16, 2020), https://www.nytimes.com/2020/03/15/world/europe/coronavirus-inequality.html [https://perma.cc/8F5C-YUKE]. 
activities have disproportionately burdened people living in low-income households, people with disabilities, people of color, and women. ${ }^{45}$ At the same time, the severe illnesses and deaths that have continued to occur in spite of public health responses have been disproportionately concentrated among people of color, disabled people, and people from low-income families as well. ${ }^{46}$

In Part II, we argue that fundamentally individualistic employment and antidiscrimination laws have undermined - rather than supported-workers' ability to protect themselves and others. The law has failed to protect people who live and work in congregate institutions ${ }^{47}$ (including nursing homes, prisons, jails, detention facilities, factories, warehouses, and schools) and thus has failed to protect the broader communities with which these institutions are interconnected. Together, public health and employment laws have put the onus on individuals to adopt protective behaviors without providing them with the supports, accommodations, and protections they

45. See, e.g., Megan Kuhfeld, James Soland \& Beth Tarasawa, Projecting the Potential Impact of COVID-19 School Closures on Academic Achievement, 49 EDUC. RESEARCHER 549 (2020); Lauren Bauer, Kristen E. Broady, Wendy Edelberg \& Jimmy O’Donnell, Ten Facts About COVID-19 and the U.S. Economy, BRoOKINGS (Sept. 17, 2020), https://www.brookings.edu/research/ten-facts-about-covid-19-and-the-u-s-economy/

[https://perma.cc/D679-KYLL]; Tom Ridge \& Ted Kennedy Jr., Opinion, People with Disabilities See Huge Job Losses; Will Pandemic Roll Back ADA Gains?, HILl (July 22, 2020, 9:30 AM), https://thehill.com/opinion/civil-rights/508221-people-with-disabilities-see-huge-joblosses-will-pandemic-roll-back-ada [https://perma.cc/9BWK-S6LL]; Bram Sable-Smith, Pandemic Upends the Lives of People with Disabilities - and of their Caregivers, KAISER HEALTH NEWS (Jun. 17, 2020), https://khn.org/news/pandemic-upends-the-lives-of-people-withdisabilities-and-of-their-caregivers/ [https://perma.cc/S978-2Q5H]; Julie Kashen, Sarah Jane Glynn \& Amanda Novello, How COVID-19 Sent Women's Workforce Progress Backward: Congress' \$64.5 Billion Mistake, CTR. FOR AM. Progress (Oct. 30, 2020, 9:04 AM), https://www.americanprogress.org/issues/women/reports/2020/10/30/492582/covid-19-sentwomens-workforce-progress-backward/ [https://perma.cc/7USM-5FC4].

46. Samrachana Adhikari, Nicholas P. Pantaleo, Justin M. Feldman, Olugbenga Ogedegbe, Lorna Thorpe \& Andrea B. Troxel, Assessment of Community-Level Disparities in Coronavirus Disease 2019 (COVID-19) Infections and Deaths in Large US Metropolitan Areas, 3 JAMA NeTWORK OPEN e2016938 (2020); Nancy Krieger, Pamela D. Waterman \& Jarvis T. Chen, COVID-19 and Overall Mortality Inequities in the Surge in Death Rates by Zip Code Characteristics: Massachusetts, January 1 to May 19, 2020, 110 AM. J. PuB. Health 1850 (2020); Daniel Wood, As Pandemic Deaths Add Up, Racial Disparities Persist-and in Some Cases Worsen, NPR (Sept. 23, 2020, 1:01 PM), https://www.npr.org/sections/healthshots/2020/09/23/914427907/as-pandemic-deaths-add-up-racial-disparities-persist-and-in-somecases-worsen [https://perma.cc/3L9E-QAML].

47. Michael Grabell, Bernice Yeung \& Maryam Jameel, Millions of Essential Workers Are Being Left Out of COVID-19 Workplace Safety Protections, Thanks to OSHA, ProPuBLICA (Apr. 16, 2020, 7:52 PM), https://www.propublica.org/article/millions-of-essential-workers-are-beingleft-out-of-covid-19-workplace-safety-protections-thanks-to-osha [https://perma.cc/6LU8FDCN]. 
need to do so. In Part III, we chart a course for a more just approach - for this pandemic and the next one-built on a core commitment to social solidarity in public health law and employment and antidiscrimination law.

We identify three key areas for reform. First, public health law should prioritize supports that create the conditions required to mitigate the spread of infection; it should deemphasize punitive measures targeting individuals. Second, employment law should protect workers from infection, including through workplace safety, privacy, and antidiscrimination protections that enable them to adopt protective health behaviors. Finally, for individuals for whom returning to work would be especially unsafe-whether because their employers maintain particularly dangerous conditions or because of their own, or their family members', underlying health conditions-employment law should remove any obligation to return while the special dangers associated with the pandemic persist.

In addition to making concrete proposals for reform, our argument makes a number of contributions to the academic literature in both public health and employment law. We add to the prior literature by showing that a broad vision of public health law that encompasses action on the social determinants of health in "non-health" sectors such as employment and antidiscrimination law is not merely tenable; it is essential. ${ }^{48} \mathrm{We}$ believe the U.S. experience with the coronavirus pandemic puts the final nail in the coffin of the old public health, with its cramped focus on microbial and behavioral

48. Compare Epstein, supra note 38 (defending the "old" public health and arguing that the new public health threatens individual liberty), and Hall, supra note 38 (arguing that a broader vision of public health law poses threats to individual liberty and coherence of the field), and Rothstein, Rethinking the Meaning of Public Health, supra note 38 (arguing for a narrow scope for public health law that does not encompass action on the social determinants of health based on concerns about individual liberty and coherence of the field), and Rothstein, The Limits of Public Health, supra note 38, at 84 (arguing for "a narrow, more precise definition of public health instead of the open-ended and impractically broad one suggested by Goldberg"), and Gostin, supra note 39 (arguing that a broad vision of public health law encompassing action to ameliorate poverty and discrimination threatens the coherence and perceived scientific neutrality of the field), and GosTIN, supra note 39, at 41 (describing a "dilemma" whereby "[i]f it conceives of itself too narrowly, public health will be accused of lacking vision[,]" but if "public health conceives of itself too expansively, .... [t] he field will lose its ability to explain its mission and functions in comprehensible terms and, consequently, to sell public health in the marketplace of politics and priorities"), with Daniel S. Goldberg, In Support of a Broad Model of Public Health: Disparities, Social Epidemiology and Public Health Causation, 2 PuB. HeAlth Ethics 70 (2009) (arguing that a narrow vision of public health law and policy is untenable in light of the findings of social epidemiology regarding the causes of health disparities), and Wiley, supra note 20, at 213 (arguing that a narrow vision of public health law would disconnect it from the inherently interventionist and progressive foundations of public health science and practice), and GosTIN \& WILEY, supra note 28, at 35 (embracing a broad vision of public health law with a focus on the "underlying social, economic, and environmental causes of injury and disease" while acknowledging the criticisms of the new public health). 
interventions. ${ }^{49}$ Individualistic strategies to change behavior have been utterly unsuccessful in the face of COVID-19. ${ }^{50}$ What are needed are solidaristic efforts to create the social and economic conditions required for people to protect themselves and others. To the "so what?" critique raised by some commentators who say they support commitments to socioeconomic justice, social solidarity, and racial equality but question the value of characterizing them as public health issues, ${ }^{51}$ we offer a resounding reply. We do more than merely point to public health impacts as a reason to do something about the social determinants of health and leaving it at that. Our collaboration - as a public health law scholar and a scholar of employment and antidiscrimination law-demonstrates the power of placing public health principles at the center of legal frameworks that govern "non-health" sectors and placing social solidarity at the center of public health. ${ }^{52}$

And we make two distinct contributions to the employment and antidiscrimination law literature. The first has to do with the normative foundations of the field. Prior academic discussions of employment and antidiscrimination law have identified a diverse set of justifications for legal regulation in this area, notably including economic efficiency, ${ }^{53}$ individual

49. GOSTIN \& WILEY, supra note 28, at 21-23.

50. See Covid in the U.S.: Latest Map and Case Count, N.Y. TIMES, https://www.nytimes.com/interactive/2020/us/coronavirus-us-cases.html [https://perma.cc/Z8ZU-GGBZ] (Nov. 3, 2020, 8:45 PM) (reporting COVID-19 cases, with details on cases at colleges, prisons, and nursing homes).

51. See, e.g., Hall, supra note 38, at S208 ("Beyond the public health arena, there are other good reasons for the government to pursue the more general aims of education, taxation, regulation, and redistribution, but these are broader social and economic policies or they belong to legal realms other than health. Public health advocates can be commended for calling our attention to the health implications of social disparities, but health promotion should not be the primary objective of corrective measures."); Rothstein, The Limits of Public Health, supra note 38 , at 86 ("[C]oncerns about social justice should play a part in priority setting for public health. My point is simply that resolution of underlying socioeconomic and political problems is beyond the domain of public health.").

52. See Gostin \& WILEY, supra note 28 , at 35 ("[P]ublic health advocates can introduce public health problem-solving models into the work of [experts in] sectors such as agriculture, housing, and transportation. Collaboration, not colonization should be the model for public health strategies that cut across 'non-health' sectors."); see also Scott Burris, Alexander C. Wagenaar, Jeffrey Swanson, Jennifer K. Ibrahim, Jennifer Wood \& Michelle M. Mello, Making the Case for Laws that Improve Health: A Framework for Public Health Law Research, 88 MILBANK Q. 169, 176 (2010) (calling for collaborative and interdisciplinary research on the impacts of "incidental public health law, that is, the effects on population health of law, agencies, and private actors not commonly understood to be pursuing a public health mission"). For another such collaboration, see Harris \& Pamukcu, supra note 31, at 762-63 (stating that "[i]n this Article, we-a critical race theorist and a health justice lawyer - argue that subordination is a public health problem.").

53. See, e.g., Alan Hyde, What Is Labour Law?, in BOUNDARIES AND FrONTIERS OF LABOUR LAW 37 (Guy Davidov \& Brian Langille eds., 2006); Stewart J. Schwab, Predicting the Future of Employment Law: Reflecting or Refracting Market Forces?, 76 IND. L.J. 29, 33 (2001). 
fairness, ${ }^{54}$ antisubordination and social equality, ${ }^{55}$ and redistribution. ${ }^{56}$ Although all of these normative principles are implicated in this context and inform our account, we bring to the foreground an additional justification for employment and antidiscrimination law-to promote solidarity by ensuring that the burdens and benefits of measures that serve the public as a whole are shared equitably. Social solidarity may offer a useful way of understanding the application of these bodies of law in other health-related contexts as well, such as genetic discrimination and workplace injuries. Second, and perhaps more significantly, we show that the attribution of fault and responsibility is a persistent obsession of employment and antidiscrimination law. Prior work, including some of our own, has pointed to dynamics like these in the application of particular doctrines and programs. ${ }^{57}$ But we go beyond those prior accounts by demonstrating that the fault/responsibility paradigm is pervasive - even in contexts such as workers' compensation where the law formally and explicitly rejects fault as a basis for imposing liability. This is a point that should be of broad interest to employment and public health law scholars alike.

\section{The Personal Responsibility Paradigm AND the Limits OF THE}

\section{U.S. PANDEMIC RESPONSE}

The Centers for Disease Control and Prevention's (CDC) guidance for community mitigation of COVID-19 prominently features a commitment to "emphasizing individual responsibility for implementing recommended personal-level actions . . . particularly in ways that protect persons at

54. See, e.g., Noah D. Zatz, Disparate Impact and the Unity of Equality Law, 97 B.U. L. REV. 1357, 1374 (2017).

55. See, e.g., Samuel R. Bagenstos, Employment Law and Social Equality, 112 MicH. L. REV. 225, 235 (2013).

56. See, e.g., Samuel R. Bagenstos, Consent, Coercion, and Employment Law, 55 HARV. C.R.-C.L. L. REV. 409, 441, 452 (2020).

57. See Samuel R. Bagenstos, The Future of Disability Law, 114 YALE L.J. 1, 54 (2004) [hereinafter Bagenstos, Future of Disability Law] (describing how courts have read the Americans with Disabilities Act narrowly to limit its accommodation mandate to cases that seem intuitively to involve employer fault and responsibility); Samuel R. Bagenstos, The Structural Turn and the Limits of Antidiscrimination Law, 94 CALIF. L. REV. 1, 3-4 (2006) [hereinafter Bagenstos, Structural Turn] (arguing that a similar dynamic will undercut any effort to use antidiscrimination law to root out structural bias); Lindsay F. Wiley, Shame, Blame, and the Emerging Law of Obesity Control, 47 U.C. DAVIS L. REV. 121, 153-58 (2013) (arguing that workplace wellness programs ostensibly intended to improve employees' health are rooted in individualistic notions of shame and blameworthiness and penalize employees based on their failure to attain certain health markers, rather than fostering employer responsibility for creating healthier workplaces). Recent work on the "tortification" of antidiscrimination law sounds similar themes. See, e.g., Sandra F. Sperino, Discrimination Law: The New Franken-Tort, 65 DEPAUL L. REV. 721 (2016). 
increased risk of severe illness." ${ }^{58}$ Framing the threat of disease in terms of personal responsibility for behaviors that are within the control of individuals is deeply rooted in social psychology. ${ }^{59}$ It is also highly protective of business interests and fiscal conservatism. ${ }^{60}$ In the coronavirus pandemic, the ethos of personal responsibility has served to deflect blame from government failures. But it is best understood as a strategy of last resort given the abdication of federal responsibility for funding and coordinating a modern response based on testing, tracing, and supported isolation. ${ }^{61}$

58. Community Mitigation Resources, CTRS. FOR DiSEASE CONTROL \& PREVENTION, https://www.cdc.gov/coronavirus/2019-ncov/php/open-america/community-mitigationconcepts.html [https://perma.cc/E6LX-LE3T] (June 29, 2020).

59. Charles E. RosenberG, EXPlaining EPIDEMICS AND Other STUdies IN THE History OF MEDICINE 274 (1992) ("The desire to explain sickness and death in terms of volition - of acts done or left undone - is ancient and powerful. The threat of disease provides a compelling reason to find prospective reassurance in aspects of behavior subject to individual control."); Christian S. Crandall \& Rebecca Martinez, Culture, Ideology, and Antifat Attitudes, 22 PersonaliTy \& SOC. PSYCH. BULL. 1165, 1166 (1996) (attributing health problems to personal failures "serves a symbolic, or value-expressive function ...., reinforcing a worldview consistent with a belief in a just world, self-determination, the Protestant work ethic, self-contained individualism, and the notion that people get what they deserve.").

60. See, e.g., Lindsay F. Wiley, Micah L. Berman \& Doug Blanke, Who's Your Nanny? Choice, Paternalism and Public Health in the Age of Personal Responsibility, 41 J.L. MED. \& ETHICS 88, 90 (2013) ("Many people do not want their own wealth to be redistributed to help others. They do not want their own choices restricted simply because others are making bad choices. And so they argue that those other people's problems are a matter of 'personal responsibility."').

61. There has been remarkable consensus among public health experts that testing, tracing, and supported isolation is the key to a more targeted response. See, e.g., Linda Lacina, WHO Coronavirus Briefing: Isolation, Testing and Tracing Comprise the 'Backbone' of Response, WORLD ECON. F. (Mar. 18, 2020), https://www.weforum.org/agenda/2020/03/testing-tracingbackbone-who-coronavirus-wednesdays-briefing/ [https://perma.cc/JFC6-EPB6]; Geoff Brumfiel, To End the Coronavirus Crisis We Need Widespread Testing, Experts Say, NPR (Mar. 24, 2020, 11:26 AM), https:/www.npr.org/sections/health-shots/2020/03/24/820157519/to-endthe-coronavirus-crisis-we-need-widespread-testing-experts-say [https://perma.cc/Z6Y3-XH84]; Danielle Allen et al., Roadmap to Pandemic Resilience: Massive Scale Testing, Tracing, AND SUPPORTEd ISOlation (TTSI) AS THE PATH to PANDEMIC RESILIENCE FOR A FrEE SOCIETY 7, 38 (Apr. 20, 2020), https:/ethics.harvard.edu/files/center-forethics/files/roadmaptopandemicresilience_updated_4.20.20.pdf [https://perma.cc/78HM-5P3N] (noting that " $[\mathrm{t}] \mathrm{o}$ succeed, isolation must be supported with job protections, resource support, and health care" and urging Congress to appropriate sufficient funds for testing, tracing, and supported isolation); Franco Ordoñez, Ex-Officials Call for $\$ 46$ Billion for Tracing, Isolating in Next Coronavirus Package, NPR (Apr. 27, 2020, 5:13 AM), https://www.npr.org/2020/04/27/845165404/ex-officials-call-for-46-billion-for-tracingisolating-in-next-coronavirus-packa [https://perma.cc/NKF9-SJA7]. 


\section{A. From Failed Community Containment to Failed Community Mitigation}

In the face of a global pandemic, the goals of governmental responses may differ from place to place and time to time. In the early days of the pandemic, the focus of U.S. health officials was on containment-preventing the epidemic from reaching our shores by isolating and quarantining travelers and their contacts before community transmission could become widespread. ${ }^{62}$ When containment efforts failed in the United States, the focus shifted to mitigation - slowing the spread of infection to flatten the curve of the epidemic. ${ }^{63}$ Some advocated for a stronger response aimed at suppression-crushing the curve to very low levels of community transmission by reducing the viral reproduction number $\left(\mathrm{R}_{0}\right)$ to below $1 .{ }^{64}$

62. See Rochelle P. Walensky \& Carlos del Rio, Opinion, From Mitigation to Containment of the COVID-19 Pandemic: Putting the SARS-CoV-2 Genie Back in the Bottle, 323 JAMA 1889, 1889 (2020) ("As part of pandemic preparedness, epidemiologists promote 'containment strategies' designed to prevent community transmission.”); see also Containment, A DICTIONARY OF EPIDEMIOLOGY (Miquel Porta ed., 5th ed. 2008) (defining containment as "regional eradication of communicable disease").

63. Walensky \& del Rio, supra note 62, at 1889 ("When disease outpaces containment, countries rely on "mitigation strategies."'). The now-ubiquitous phrase "flatten the curve" refers to a mitigation strategy identified through historical analysis of the 1918 influenza pandemic and endorsed in U.S. pandemic influenza plans in 2007. See CTRS. FOR DiseASE CONTROL \& PreVention, INTERIM PRE-PANDEMIC PlanNing Guidance 9 (2007), https://stacks.cdc.gov/view/cdc/11425 [https://perma.cc/95K9-97QZ] ("Reshaping the demand for healthcare services by using [nonpharmaceutical interventions (NPIs), including social distancing] . . . means reducing the burdens on the medical and public health infrastructure by decreasing demand for medical services at the peak of the epidemic and throughout the epidemic wave; by spreading the aggregate demand over a longer time; and, to the extent possible, by reducing net demand through reduction in patient numbers and case severity."); see also Noreen Qualls et al., Community Mitigation Guidelines To Prevent Pandemic Influenza-United States, 2017, 66 CDC Morbidity \& Mortality Whly. ReP. 1, 18 (2017), https://www.cdc.gov/mmwr/volumes/66/rr/pdfs/rr6601.pdf [https://perma.cc/MY42TA4C] ("Although there is limited empirical evidence supporting the effectiveness of implementing any individual measure alone (other than school closures and dismissals), the evidence for implementing multiple social distancing measures in combination with other NPIs includes systematic literature reviews, historical analyses of the 1918 pandemic, and mathematical modeling studies ....").

64. Neil M. Ferguson et al., Imperial Coll. London, Report 9: IMPACt of NonPharmaceutical InTERVEnTIONS (NPIs) To ReducE COVID-19 MORTALITY AND HEALTHCARE DEMAND 1 (2020) ("Two fundamental strategies are possible: (a) mitigation, which focuses on slowing but not necessarily stopping epidemic spread - reducing peak healthcare demand while protecting those most at risk of severe disease from infection, and (b) suppression, which aims to reverse epidemic growth, reducing case numbers to low levels and maintaining that situation indefinitely."); see also Harvey V. Fineberg, Editorial, Ten Weeks To Crush the Curve, 382 NEW ENG. J. MED. e37 (2020) ("The aim [of suppression] is not to flatten the curve; the goal is to crush the curve."). 
In the absence of effective vaccines and therapeutics, each of these strategies relies on measures implemented in community, rather than clinical, settings. Community containment to prevent widespread transmission relies on impeccable government coordination and ready access to testing to screen travelers and put them into isolation (if suspected of being infected) or quarantine (if suspected of having been exposed), then doing the same for their traced contacts. ${ }^{65}$ Community mitigation to slow the spread of disease once transmission has become widespread relies on personal hygiene (handwashing and mask-wearing) and reduction in personal movement and business operations to decrease social mixing and increase social distance among people who don't share a household. ${ }^{66}$ Community suppression strategies to drive down the rate of transmission to very low levels rely on comprehensively screening the population for infection through widespread testing, isolating those who test positive for as long as their infection is communicable, and tracing and quarantining their close contacts for the duration of the incubation period. ${ }^{67}$

Infectious-disease-control regulations and emergency orders facilitate community containment, mitigation, and suppression measures. ${ }^{68}$ Federal, state, and local statutes authorize isolation and quarantine of individuals who are reasonably believed to be infected or to have been exposed. ${ }^{69}$ When testing is available, health officials, employers, and other private institutions are empowered to require it. ${ }^{70}$ They also may require symptom checks and other screening tools for individualized risk assessment. ${ }^{71}$ In the absence of widespread testing, health officials have acted on the assumption that anyone

65. See Walensky \& del Rio, supra note 62, at 1889 ("For . . (COVID-19), countries like South Korea - an example of successful containment — had a coordinated governmental response, testing on a massive scale, and prompt contact tracing and quarantine.").

66. Id. ("Mitigation relies on nonpharmaceutical interventions such as hand hygiene, travel restrictions, school closures, and social distancing. While a blunt and inconvenient tool, social distancing has proven in pandemic influenza (in both 1918 and 2009) to reduce and delay peak attack rates and mortality."); see also STANLEY M. LEMON ET AL., INST. OF MED. OF THE NAT'L ACAds., Ethical And Legal Considerations in Mitigating PANDEMiC Disease 5 (2007).

67. See FERGUSON ET AL., supra note 64, at 6, 15 (assuming testing, tracing, quarantine, and isolation in addition to social distancing among the general population).

68. See Wiley, supra note 42, at 69-81.

69. State Quarantine and Isolation Statutes, NAT'L Conf. OF ST. LegIS. (Aug. 7, 2020), https://www.ncsl.org/research/health/state-quarantine-and-isolation-statutes.aspx [https://perma.cc/M4X7-NQ5D].

70. Interim Guidance for Businesses and Employers Responding to Coronavirus Disease 2019 (COVID-19), May 2020, CTrS. FOR Disease CONTROL \& Prevention, https://www.cdc.gov/coronavirus/2019-ncov/community/guidance-business-response.html [https://perma.cc/M672-J2QG] (May 6, 2020).

71. Id. 
could be a silent carrier of infection. ${ }^{72}$ That assumption is prudent in light of evidence that pre-symptomatic and asymptomatic transmission may play a significant role in spreading the disease. ${ }^{73}$ Officials thus have recommended or mandated various infection control protocols. ${ }^{74}$ These have included maskwearing and physical distancing (staying six feet apart), ${ }^{75}$ among other measures. They have also included various orders to increase social distance and decrease social mixing (reducing the number of contacts among nonhousehold members population-wide). These orders have restricted public services, limited the operations of businesses, and required the general population to stay at home except for work and errands deemed essential by state and local officials. ${ }^{76}$ All of these measures have placed the onus on individuals to mitigate transmission of, and shield themselves from, exposure to the virus. Individuals must do so while coping with job loss and other secondary harms caused by social, cultural, and economic disruption.

\section{Isolation and Quarantine of Infected and Exposed Individuals}

In public health and legal terminology, isolation and quarantine have distinct meanings, but both play a particularly important role in preventing the spread of infection from place to place and person to person. Isolation refers to separation of individuals known or believed to be infected from others during the period of infectiousness. ${ }^{77}$ For those who are severely ill, isolation is typically ensured by following special infection-control protocols

72. Social Distancing, CTRS. FOR DiseASE CONTROL \& Prevention, https://www.cdc.gov/coronavirus/2019-ncov/prevent-getting-sick/social-distancing.html [https://perma.cc/S2RB-4M2T] (July 15, 2020).

73. Pandemic Planning Scenarios, Ctrs. For Disease Control \& Prevention, https://www.cdc.gov/coronavirus/2019-ncov/hcp/planning-scenarios.html

[https://perma.cc/7H3P-BREP] (Sept. 10, 2020).

74. CTRS. FOR Disease CONTROL \& PREVENTION, supra note 72.

75. Although physical distancing and social distancing are now used interchangeably in many educational materials for the general public and some U.S. executive orders, we use the terms to refer to two distinct interventions. See infra text accompanying note 147 . We use physical distancing to refer to the actions individuals take to remain six feet away from others as much as possible while outside the home. We use social distancing to refer to the actions governments and other institutions take, such as closing gathering places and implementing distance education and telework, to reduce interactions among people from different households. Social distancing in this sense appears to have been derived by CDC and WHO pandemic-preparedness workgroups from sociological terms - social distance and social mixing-used to describe social networks that connect individuals. These terms appear to have entered the epidemiology lexicon through studies of how social networks influence HIV transmission. See Wiley, supra note 43, 53 n.1.

76. See Wiley, supra note 42, at 69-81.

77. Quarantine and Isolation, CTRS. FOR DisEASE CONTROL \& PREvention, https://www.cdc.gov/quarantine/index.html [https://perma.cc/MPA6-BP2S] (Sept. 29, 2017). 
in the hospital. ${ }^{78}$ But for the mildly ill-and those with severe illness in situations where hospitals are overwhelmed-health officials may recommend or require isolation at home. ${ }^{79}$ Quarantine refers to separation of individuals known or believed to be exposed to infection from others during the incubation period between exposure and onset of symptoms or a positive test result. ${ }^{80}$ Under some circumstances, quarantine may be carried out in a facility outside the home. In many cases, however, individuals are urged - or ordered - to stay home during the incubation period. ${ }^{81}$

In January 2020, U.S. federal officials initiated containment strategies in response to reports of an outbreak of pneumonia in Wuhan, China, caused by a novel coronavirus strain. ${ }^{82}$ These strategies sought to identify infected and exposed travelers entering the United States from China and isolate or quarantine them before they could infect others. ${ }^{83}$ On January 29 , the State Department repatriated hundreds of Americans from Wuhan ${ }^{84}$ and placed them under federal quarantine orders. ${ }^{85}$ They were held in governmentprovided facilities at March Air Reserve Base in California while being monitored for symptoms and tested for infection during a fourteen-day

78. Infection Control Guidance, CTRS. FOR Disease CONTROL \& Prevention, https:/www.cdc.gov/coronavirus/2019-ncov/hcp/infection-control-

recommendations.html?CDC_AA_refVal=https $\% 3 \mathrm{~A} \% 2 \mathrm{~F} \% 2 \mathrm{Fwww} . c d c . g o v \% 2 \mathrm{Fcoronavirus} \% 2$ F2019-ncov\%2Finfection-control\%2Fcontrol-recommendations.html [https://perma.cc/84LHELRV] (Nov. 4, 2020).

79. Qualls et al., supra note 63, at 1 (recommending "voluntary home isolation of ill persons").

80. CTRS. For Disease CONTROL \& PREVEnTION, supra note 77.

81. Qualls et al., supra note 63, at 1 (recommending "voluntary home quarantine of exposed household members" of people known or suspected of being infected).

82. Erin Schumaker, Timeline: How Coronavirus Got Started, ABC News (Sept. 22, 2020, 8:55 AM), https://abcnews.go.com/Health/timeline-coronavirus-started/story?id=69435165 [https://perma.cc/8TCC-6QVV].

83. Anita Patel, Daniel B. Jernigan \& 2019-nCoV CDC Response Team, Initial Public Health Response and Interim Clinical Guidance for the 2019 Novel Coronavirus OutbreakUnited States, December 31, 2019-February 4, 2020, 69 CDC MORBIDITY \& MORTALITY WKLY. REP. 140, 142 (2020), https://www.cdc.gov/mmwr/volumes/69/wr/pdfs/mm6905e1-H.pdf [https://perma.cc/3H9M-6JTM].

84. Press Release, Ctrs. for Disease Control \& Prevention, HHS and CDC Receive Flight Carrying Repatriated US Citizens (Jan. 29, 2020), https://www.cdc.gov/media/releases/2020/s0129-repatriated-US-citizens.html [https://perma.cc/R3R4-ZKVS].

85. Press Release, Ctrs. for Disease Control \& Prevention, Media Telebriefing: Update on 2019 Novel Coronavirus (2019-nCoV) (Jan. 31, 2020), https://www.cdc.gov/media/releases/2020/t0131-2019-novel-coronavirus.html [https://perma.cc/8SSB-97ZW]. 
incubation period ${ }^{86}$ None tested positive. ${ }^{87}$ On January 30, CDC confirmed the first known case of human-to-human transmission occurring within the United States. ${ }^{88}$ A person who had acquired the infection overseas (but whose infection had not been detected at the border) had transmitted it to a member of their household. ${ }^{89}$ On January 31, Health and Human Services Secretary Alex Azar issued a public health emergency determination. ${ }^{90}$

Meanwhile, many more travelers entered the United States from China and other areas with severe outbreaks, including Italy. ${ }^{91} \mathrm{~A}$ few reported to hospitals with symptoms and were diagnosed with COVID-19. ${ }^{92}$ State and local authorities put significant resources into confirming these early patients were complying with the requirement to self-isolate upon their release from the hospital. .93 "In the beginning, dozens of investigators, called 'cluster

86. Press Release, Ctrs. for Disease Control \& Prevention, CDC Issues Federal Quarantine Order to Repatriated U.S. Citizens at March Air Reserve Base (Jan. 31, 2020), https://www.cdc.gov/media/releases/2020/s0131-federal-quarantine-march-air-reservebase.html [https://perma.cc/TN7L-Q7GM].

87. Bill Chappell, 195 Americans Released from Coronavirus Quarantine at Southern California Air Base, NPR (Feb. 11, 2020, 3:13 PM), https://www.npr.org/sections/healthshots/2020/02/11/804915231/195-americans-are-released-from-coronavirus-quarantine-atcalifornia-air-base [https://perma.cc/DFU7-UCVY].

88. Press Release, Ctrs. for Disease Control \& Prevention, CDC Confirms Person-to-Person Spread of New Coronavirus in the United States (Jan. 30, 2020), https://www.cdc.gov/media/releases/2020/p0130-coronavirus-spread.html [https://perma.cc/GL7R-4DJ6].

89. Id. The CDC later surveyed evidence suggesting that limited U.S. community transmission among people with no known connection to travel within China likely began in late January or early February. Michelle A. Jorden et al., Evidence for Limited Early Spread of COVID-19 Within the United States, January-February 2020, 69 CDC MORBIDITY \& MORTALITY WKLY. REP. 680, 682 (2020).

90. Alex M. Azar II, Determination that a Public Health Emergency Exists, U.S. DEP'T OF HeAlth \& Hum. SERVs. (Jan. 2020), https:/www.phe.gov/emergency/news/healthactions/phe/Pages/2019-nCoV.aspx [https://perma.cc/9DC7-49EJ].

91. Pierre Thomas, Jack Date, Sony Salzman \& Eric M. Strauss, Disaster in Motion: 3.4 Million Travelers Poured into US as Coronavirus Pandemic Erupted, ABC NEWs (Apr. 2, 2020, 9:19 AM), https://abcnews.go.com/Politics/disaster-motion-34-million-travelers-poured-uscoronavirus/story?id=69933625 [https://perma.cc/WDA5-2Z8G].

92. Daniel B. Jernigan \& CDC COVID-19 Response Team, Update: Public Health Response to the Coronavirus Disease 2019 Outbreak-United States, February 24, 2020, 69 CDC MORBIDITY \& MORTALITY WKLY. REP. 216, 217 (2020), https://www.cdc.gov/mmwr/volumes/69/wr/pdfs/mm6908e1-H.pdf [https://perma.cc/U5P32A4T].

93. Emily Baumgaertner, The Inside Story of How California Failed Mass Coronavirus Testing, L.A. TIMES (July 12, 2020, 6:00 AM), https:/www.latimes.com/california/story/202007-12/california-fail-coronavirus-testing-covid-start [https://perma.cc/CN74-THE9] (describing efforts to support isolation of the first person to be diagnosed with COVID-19 following his 
busters,' worked each case to try to contain the spread of the coronavirus." 94 In addition to tracing the infected person's contacts, the investigators offered critical supports to enable the infected person to stay home. "They functioned as all-inclusive personal assistants: arranging child care, setting up WiFi, coordinating grocery drop-offs." 95

By late February, it became clear that in spite of containment efforts, people who hadn't traveled overseas and hadn't encountered someone known to be infected were suffering from COVID-19. ${ }^{96}$ Many state and local health departments issued recommendations or orders directing people to stay home if they were ill with COVID-19. ${ }^{97}$ But testing materials were in short supply. ${ }^{98}$ The FDA had restricted testing to specifically certified labs. ${ }^{99}$ Early CDC guidelines had directed health-care providers to refer patients for testing only if they had history of travel to China, had been exposed to a person known to have been infected, or were hospitalized for pneumonia or acute respiratory distress. ${ }^{100}$ Lack of access to testing meant that virtually all of the people

release from the hospital). The man had previously been identified as a traveler who had returned to the United States from Wuhan. Ian Wheeler, Orange County Coronavirus Patient Released, in Good Condition, Health Officials Say, Orange CNTY. Reg. (Feb. 5, 2020, 10:30 AM), https://www.ocregister.com/2020/02/04/risk-of-catching-coronavirus-in-so-cal-is-low-healthofficials-say/ [https://perma.cc/9FEZ-V7MN].

94. Baumgaertner, supra note 93.

95. Id.

96. See Press Release, Ctrs. for Disease Control \& Prevention, CDC Confirms Possible Instance of Community Spread of COVID-19 in U.S. (Feb. 26, 2020), https://www.cdc.gov/media/releases/2020/s0226-Covid-19-spread.html [https://perma.cc/8ZRHJBYG]; Press Release, Ctrs. for Disease Control \& Prevention, CDC Announces Additional COVID-19 Presumptive Positive Cases (Feb. 28, 2020), https://www.cdc.gov/media/releases/2020/s0228-additional-COVID-19-cases.html [https://perma.cc/2V7D-S8BF].

97. See, e.g., Local Health Officials Announce New Recommendations To Reduce Risk of Spread of COVID-19, King CNTy. Pub. Health News \& Blog (Mar. 4, 2020), https://www.kingcounty.gov/depts/health/news/2020/March/4-covid-recommendations.aspx [https://perma.cc/F5YN-3K37] ("Public Health is recommending, but not requiring, the following steps ... people should not go out when they are sick.").

98. Michael D. Shear et al., The Lost Month: How a Failure To Test Blinded the U.S. to Covid-19, N.Y. TIMES (Apr. 1, 2020), https://www.nytimes.com/2020/03/28/us/testingcoronavirus-pandemic.html [perma.cc/6TVD-C3W2].

99. 02/18/2020: Lab Advisory: Reminder: COVID-19 Diagnostic Testing, CTRS. FOR DiseASE CONTROL \& PREVENTION, https://www.cdc.gov/csels/dls/locs/2020/reminder_covid19_diagnostic_testing.html [https://perma.cc/GV54-QPVL] (Mar. 20, 2020).

100. Update and Interim Guidance on Outbreak of 2019 Novel Coronavirus (2019-nCoV), Ctrs. FOR Disease CONTROL \& PREVEntion (Feb. 1, 2020, 9:00 AM), https://emergency.cdc.gov/han/HAN00427.asp [https://perma.cc/9MMN-DGJC]; Update and Interim Guidance on Outbreak of Coronavirus Disease 2019 (COVID-19), CTRS. FOR DISEASE CONTROL \& PREVENTION (Feb. 28, 2020, 3:05 https://emergency.cdc.gov/han/2020/HAN00428.asp [https://perma.cc/5AWW-6KUX]. 
being asked to stay home (potentially with adverse consequences for their employment) weren't able to confirm whether they actually posed a risk of transmitting the virus to others or were simply experiencing very common symptoms like a cough or a stuffy nose. ${ }^{101}$

\section{Social Distancing in the General Population}

"By early March, after federal officials finally announced changes to expand testing, it was too late. With the early lapses, containment was no longer an option. The tool kit of epidemiology would shift-lockdowns, social disruption, intensive medical treatment-in hopes of mitigating the harm." 102 On March 16, 2020, "seven local health officers in the San Francisco Bay Area followed the examples set by China and Italy and issued mandatory shelter-in-place orders and prohibitions on all onsite business operations deemed nonessential." ${ }^{103}$ Over the next two weeks, the majority of state governors issued similar orders. ${ }^{104}$ In early April, as more states added stay-at-home orders, others issued extensions. ${ }^{105}$ These measures were aimed at increasing social distance and decreasing social

101. See, e.g., Chi. Admin. Order No. 2020-1 (Mar. 18, 2020), https://www.chicago.gov/content/dam/city/depts/cdph/HealthProtectionandResponse/Order\%20 re\%20Shelter\%20in\%20Place\%20FINAL.pdf [https://perma.cc/2AJC-9XWW] (ordering residents to stay at home if they have any symptoms characteristic of COVID-19, "including, but not limited to, new onset of fever, cough, shortness of breath, congestion in the nasal sinuses or lungs, sore throat, body aches, or unusual fatigue"); see also Baumgaertner, supra note 93 (describing a woman and child who developed COVID-19 symptoms after their family member returned home from China but were not tested due to stringent CDC criteria and scarce supplies and potentially caused a subsequent outbreak among their contacts).

102. Shear et al., supra note 98.

103. See Wiley, supra note 42, at 74; City \& Cnty. of S.F. Admin. Order No. C19-07 (Mar. 16, 2020), https://sfgsa.org/sites/default/files/Document/OrderC19-07ShelterinPlace.pdf [https://perma.cc/QY48-MFZW]; Julia Prodis Sulek, Meet the Doctor Who Ordered the Bay Area's Coronavirus Lockdown, the First in the U.S., MERCURY NEWS (Mar. 29, 2020, 3:55 PM), https://www.mercurynews.com/2020/03/29/she-shut-down-the-bay-area-to-slow-thedeadly-coronavirus-none-of-us-really-believed-we-would-do-it [https://perma.cc/K4DH-QYG8] (describing the events that led seven local jurisdictions to simultaneously issue shelter-inplace orders).

104. Jennifer Kates, Josh Michaud \& Jennifer Tolbert, Stay-at-Home Orders To Fight COVID-19 in the United States: The Risks of a Scattershot Approach, KAISER FAM. FOUND. (Apr. 5, 2020), https://www.kff.org/coronavirus-policy-watch/stay-at-home-orders-to-fight-covid19 [https://perma.cc/G597-ZHYU]; see also State Data and Policy Actions To Address Coronavirus, KAISER FAM. FOUND. (Nov. 6, 2020) https://www.kff.org/health-costs/issuebrief/state-data-and-policy-actions-to-address-coronavirus/\#socialdistancing [https://perma.cc/ 5XQU-CX58] (tracking state social-distancing executive orders).

105. Kates et al., supra note 104. 
mixing among the general population. ${ }^{106}$ In the absence of widespread testing, and amid reports indicating asymptomatic carriers of infection were capable of spreading the virus, governors, mayors, and state and county health officials ordered everyone to stay at home. ${ }^{107} \mathrm{Or}$, rather, everyone except for workers officials deemed "essential." 108

Pre-pandemic discussions barely scratched the surface of the enormous disruption to individuals and communities that social distancing measures would cause. As one of us wrote (with Professor Lawrence Gostin) in 2016, "Social distancing, particularly for long durations, can severely disrupt the economy and cause loneliness and depression. ... As with many disease mitigation strategies, the vulnerable would suffer most." ${ }^{109}$ Rosemarie Tong's 2008 memoir detailing her experiences serving on an influenza task force convened by the North Carolina Department of Public Health previewed the crisis to come. ${ }^{110}$ Tong offered a worrisome warning: "[D]uring an influenza pandemic, so much would depend on society having well-developed systems to meet people's basic needs and on having adequate reservoirs of community goodwill and public service at hand." 111 Based on comments at a community meeting hosted by the task force, she reported that "most people's economic situations would determine whether they stayed home from work voluntarily. If their workplace was open and they needed the money to pay their bills, people would drag themselves to work." 112 Tong noted "the only sure ways

106. GOSTIN \& WILEY, supra note 28, at 431-33 (discussing the role of decreased social mixing and increased social distance in response to epidemics).

107. Kates et al., supra note 104.

108. Opinion, 'You're on Your Own,' Essential Workers Are Being Told, N.Y. TIMES (Apr. 20, 2020), https://www.nytimes.com/2020/04/20/opinion/osha-coronavirus.html [https://perma.cc/GK64-CE2P]; Shannon Bond, 'We're Out There' So Protect Us, Protesting Workers Tell Amazon, Target, Instacart, NPR (May 1, 2020, 4:14 PM), https://www.npr.org/2020/05/01/849218750/workers-walk-off-jobs-demand-safer-workingconditions [https://perma.cc/P29R-ZGYU]. By using the term essential, we do not mean to suggest that there is some apolitical, technocratic way of determining which workers are essential. We use the term as shorthand for the classifications that individual and collective political actors have drawn to determine which workers are allowed or required to stay on the job despite the risks posed by the pandemic. See Wiley, supra note 42, at 94-106 (discussing these classifications and litigation challenging them on equal protection and separation of powers grounds).

109. Gostin \& WILEY, supra note 28, at 432.

110. Rosemarie Tong, Shaping Ethical Guidelines for an Influenza Pandemic, in InTERnAtional Public Health Policy And Ethics 215, 215 (Michael Boylan ed., 2008).

111. Id. at 225-26 (describing the work of the North Carolina Institute of Medicine/Department of Public Health Task Force).

112. Id. at 225 . 
to prevent this state of affairs would be to force workplaces to close or to pay workers to stay home." 113

Rather than urging lawmakers to develop supports to ensure people in low-income households could weather such a crisis, some pre-pandemic plans focused on ensuring that essential workers reported for duty in spite of fears for their health. Tong, for example, noted "it would be incumbent upon government officials to get not only health care personnel but also other socially essential personnel to do their jobs." 114 Essential needs raised difficult questions: "How would food be delivered to isolated, quarantined, or socially distanced people? ... What, if anything, do workers in the food industry owe the public; and what, if anything, does the public owe them?"115

As the nature of the 2020 coronavirus pandemic shifted from "spread . . . involv[ing] people with financial resources, such as cruise-goers and international flyers," to "a disease of the socially vulnerable," 116 the supports provided during the containment stage were not extended into the mitigation phase. ${ }^{117}$ The sheer number of cases overwhelmed the limited staffing of public health agencies. ${ }^{118}$ Congress did not supply the resources that would be required for a massive ramp-up of testing, contact tracing, and supported isolation. ${ }^{119}$ The general public was ordered to self-isolate and make their own arrangements for food, medicines, and other essential needs. ${ }^{120}$ Congress appropriated funds to provide short-term support for businesses to cover payroll and to supplement unemployment benefits. ${ }^{121}$ But workers who did

113. Id.; see also Kelly D. Blake, Robert J. Blendon \& Kasisomayajula Viswanath, Employment and Compliance with Pandemic Influenza Mitigation Recommendations, 16 EMERGING INFECTIOUS DISEASES 212, 212 (2010) (“'I]nability to work from home, lack of paid sick leave, and income are associated with working adults' ability to comply and should be major targets for workplace interventions in the event of a serious outbreak.").

114. Tong, supra note 110, at 223.

115. Id. at 225.

116. Walensky \& del Rio, supra note 62, at 1890.

117. See, e.g., Taylor Dolven, No Information. No Way Off. 100,000 Crew Members Remain in Cruise Ship Limbo for Months, MiA. HeRALD (July 13, 2020, 4:36 PM), https://www.miamiherald.com/news/business/tourism-cruises/article242565281.html [https://perma.cc/35WC-TPA7].

118. Rob Stein, Pandemic Is Overwhelming U.S. Public Health Capacity in Many States. What Now?, NPR (July 28, 2020, 5:07 AM), https://www.npr.org/sections/healthshots/2020/07/28/894858475/pandemic-is-overwhelming-u-s-public-health-capacity-in-manystates-what-now [https://perma.cc/GE77-SK6T].

119. See Allen ET AL., supra note 61, at 6.

120. See, e.g., Okla. Exec. Order No. 2020-07 (Fourth Amended) (Mar. 24, 2020), https:/www.sos.ok.gov/documents/executive/1919.pdf [https://perma.cc/T6Q7-T98X]; Ga. Exec. Order No. 04.23.20.02 (Apr. 23, 2020), https://gov.georgia.gov/document/2020-executiveorder/04232002/download [https://perma.cc/S7GB-FK7E].

121. See infra Part II.B. 
not have the option of staying home were left exposed, risking their own health and potentially spreading the infection to their household members. ${ }^{122}$

Starting in late April, governors began to lift restrictions on businesses and the general public. ${ }^{123}$ Many states reopened even high-risk, non-essential businesses like bars and indoor dining. ${ }^{124}$ They did so even though the states had not met critical gating criteria. ${ }^{125}$ The White House, along with many state and local governments, had issued guidelines to ensure that social distancing interventions would be eased gradually and accompanied by a ramp-up of more targeted measures - testing, contact tracing, isolation of infected cases, and quarantine of their exposed contacts - to detect clusters and stop chains of transmission before outbreaks got out of control. ${ }^{126}$ The White House guidelines for reopening businesses, for example, adopted reasonably cautious criteria for moving from one phase to the next. ${ }^{127}$ These criteria included sustained reduction in cases or in positive tests as a percent of total tests between each phase. ${ }^{128}$ But the federal plan left states-which lack authority to deficit-spend or coordinate interstate supply chains for scarce testing supplies-largely on their own to ramp up targeted measures. ${ }^{129}$ Without support from the federal government, testing and contact tracing weren't up to the task. ${ }^{130}$ Meanwhile, some governors charged forward with

122. See FERGUSON ET AL., supra note 64, at 6 (assuming that social distancing of the entire population causes household contact rates to increase by $25 \%$ ); see also infra Part II.A.

123. Keith Collins \& Lauren Leatherby, Most States that Are Reopening Fail To Meet White

House Guidelines, N.Y. TIMES (May 7, 2020),
https://www.nytimes.com/interactive/2020/05/07/us/coronavirus-states-reopen-criteria.html [https://perma.cc/N3C8-XNA2].

124. See Alaa Elassar, This Is Where Each State Is During Its Phased Reopening, CNN, https://www.cnn.com/interactive/2020/us/states-reopen-coronavirus-trnd/

[https://perma.cc/VBW5-UELU] (May 27, 2020, 10:00 PM).

125. Collins \& Leatherby, supra note 123.

126. See Wiley, supra note 42 , at 76-79.

127. See The White House \& Ctrs. for Disease Control \& Prevention, Guidelines: Opening Up America Again, WHITE HOUSE, https://www.whitehouse.gov/openingamerica/ [https://perma.cc/45AG-HVL5].

128. Id.; Press Release, The White House, President Donald J. Trump Announces Guidelines for Opening Up America Again (Apr. 16, 2020), https://www.whitehouse.gov/briefingsstatements/president-donald-j-trump-announces-guidelines-opening-america/ [https://perma.cc/7Y8W-DMZ5].

129. Michael D. Shear et al., Inside Trump's Failure: The Rush To Abandon Leadership Role on the Virus, N.Y. TIMES (Sept. 15, 2020), https://www.nytimes.com/2020/07/18/us/politics/trump-coronavirus-response-failureleadership.html [https://perma.cc/F8XR-3EJ3] (“[The White House aides'] ultimate goal was to shift responsibility for leading the fight against the pandemic from the White House to the states. They referred to this as 'state authority handoff' . . .."); see Press Release, The White House, supra note 128; The White House \& Ctrs. for Disease Control \& Prevention, supra note 127.

130. Shear et al., supra note 98. 
reopening. ${ }^{131}$ More cautious governors were urged by the President to "liberate" their states although the White House's own criteria hadn't been satisfied. ${ }^{132}$

\section{Shielding for People Who Are Particularly Vulnerable}

At various stages in the coronavirus pandemic response, some have argued that "regular" people should go about their lives while people who are particularly vulnerable due to age or chronic conditions shelter in place. ${ }^{133}$ This strategy is distinct from social distancing to reduce the number of nonhousehold contacts among the general population. We adopt the term used by public health authorities in other countries and call it shielding. ${ }^{134}$

Some governors have imposed mandatory shielding for older people and those with particular chronic conditions as an alternative to issuing stay-athome orders for the general public. ${ }^{135}$ In April and May, as governors lifted stay-at-home orders for the general population, some ordered people over sixty-five and anyone with chronic conditions that put them at increased risk to stay at home. ${ }^{136}$ Apart from advice to "use delivery and/or curbside services whenever available," these orders made few provisions to support shielding. ${ }^{137}$

\section{Infection Control Protocols for High-Risk Settings}

Orders requiring or recommending that people stay at home while expecting workers to continue to provide for the population's necessities have

131. Ordoñez, supra note 61.

132. Shear et al., supra note 129.

133. See, e.g., Michael C. Dorf, Rethinking Generational Justice in Light of the Coronavirus Catastrophe, JUSTIA: VERDICT (Mar. 12, 2020), https://verdict.justia.com/2020/03/12/rethinkinggenerational-justice-in-light-of-the-coronavirus-catastrophe [https://perma.cc/LU3A-Z9L4] (framing this perspective as "say[ing] that older people should be left to die").

134. See, e.g., Public Health England, Guidance on Shielding and Protecting People Who Are Clinically Extremely Vulnerable from COVID-19, Gov.UK, https://www.gov.uk/government/publications/guidance-on-shielding-and-protecting-extremelyvulnerable-persons-from-covid-19/guidance-on-shielding-and-protecting-extremely-vulnerablepersons-from-covid-19 [https://perma.cc/GAZ9-V445] (Nov. 13, 2020).

135. See, e.g., Okla. Exec. Order No. 2020-07, supra note 120 ("Adults over the age of sixtyfive (65) and people of any age who have serious underlying medical conditions, collectively referred to as 'vulnerable individuals,' shall stay in their home or place of residence except for working in a critical infrastructure sector . . . and the conduct of essential errands.").

136. See, e.g., Ga. Exec. Order No. 04.23.20.02, supra note 120 (requiring all residents and visitors who meet criteria for higher risk of severe illness as defined by CDC guidelines to shelter in place except for conducting or participating in essential work and errands).

137. See, e.g., Okla. Exec. Order No. 2020-07, supra note 120. 
done little to prevent outbreaks in congregate work and residential settings. Indeed, one of the reasons that social distancing alone cannot achieve suppression or containment is that as long as essential work and errands continue, the virus continues to circulate. ${ }^{138}$ Large outbreaks in nursing homes, prisons, meatpacking plants, and distribution warehouses were reported in March and April. ${ }^{139}$ Personal protective equipment was scarce, ${ }^{140}$ and access to rapid-result testing was limited. ${ }^{141}$ Federal, state, and local officials issued guidance setting forth a wide range of infection control measures for congregate facilities and other businesses that remained open. ${ }^{142}$ But these measures were necessarily inadequate. Many relied on employees to adopt protective behaviors, such as monitoring themselves for symptoms, staying home when sick, wearing face coverings (which employers were not typically required to provide), and staying six feet apart from others, as practicable. ${ }^{143}$ Infection control protocols were expanded to virtually all businesses as state and local officials began to allow them to reopen in late April and May. ${ }^{144}$

In June and July, Sun Belt governors facing surging case counts were committed to keeping businesses open and bringing students back onsite to schools. ${ }^{145}$ They doubled down on infection control protocols in an attempt

138. Pandemic-preparedness plans consistently recommend that testing, tracing, and supported isolation and quarantine should be combined with social distancing measures. See, e.g., FERGUSON ET AL., supra note 64, at 14-16; Tong, supra note 110, at 225. They were never meant to be viewed as alternative approaches. See FERGUSON ET AL., supra note 64, at 14-16. Social distancing is intended to reduce the overall number of non-household contacts in the general public to levels that allow ramped-up public health infrastructure for testing and contact tracing to get outbreaks under control, while also ensuring the need for hospital services stays within available capacity. See id. at 6-8, 15; Laura Matrajt \& Tiffany Leung, Evaluating the Effectiveness of Social Distancing Interventions To Delay or Flatten the Epidemic Curve of Coronavirus Disease, 26 EMERGING INFECTIOUS DISEASES 1740, 1740 (2020), https://wwwnc.cdc.gov/eid/article/26/8/20-1093_article [https://perma.cc/GYX6-J72K].

139. See, e.g., Waltenburg et al., supra note 16, at 887; Wallace et al., supra note 16, at 587.

140. N.Y. TIMES, supra note 108.

141. Steven Mufson, Juliet Eilperin \& Josh Dawsey, The Scramble for the Rapid Coronavirus Tests Everybody Wants, WASH. PosT (Apr. 1, 2020, 5:24 PM), https://www.washingtonpost.com/health/2020/04/01/scramble-rapid-coronavirus-testseverybody-wants/ [https://perma.cc/S72Z-ATBN].

142. Kates et al., supra note 104; KAISER FAM. FOUND., supra note 104.

143. See, e.g., OcCupational SAfety \& HeAlth Admin., OSHA 3990-03, Guidance on PREPARING WORKPLACES FOR COVID-19, at 8-10 (2020), https://www.osha.gov/Publications/OSHA3990.pdf [https://perma.cc/83BS-X832].

144. See, e.g., Ga. Exec. Order No. 04.23.20.02, supra note 120 (setting forth detailed infection control protocols for a wide range of settings).

145. Jonathan Levin \& Emma Court, Patients Swamp Sun Belt Hospitals with Covid-19 on a Rampage (1), BloOMBerG L. (July 10, 2020, 3:20 AM), https://news.bloomberglaw.com/coronavirus/patients-swamp-sun-belt-hospitals-with-covid-19on-a-rampage [https://perma.cc/88K9-ZHE7]. 
to assure the public that returning to work, school, and in-person commerce would be safe. ${ }^{146}$ In some cases, executive orders twisted social distancing from a term describing government responsibility for closing gathering places to a matter of personal responsibility by demanding that employees maintain physical distance while being required to work ... in gathering places. ${ }^{147}$

\section{B. Unequal Benefits and Burdens}

The U.S. response to the coronavirus pandemic has distributed benefits and burdens in deeply unjust ways. Low-wage workers, racial and ethnic minority groups, immigrants, women, and other socially subordinated groups have paid disproportionately heavy economic and social costs. At the same time, some of these groups have been less able than others to reap the health benefits of community mitigation.

The burdens of community mitigation (including unemployment, disruption of education, health care, and more) have been disproportionately borne by socially subordinated groups. A May 2020 study found that people with jobs that cannot be done from home-who thus faced the highest risk of unemployment - were disproportionately those with less income, wealth, and education. ${ }^{148}$ Unsurprisingly, COVID-related job losses have been most severe for people who are younger, who have less formal education, who have lower incomes, and who identify as being part of racial and ethnic minority groups. ${ }^{149}$ A June study found that "[s]ectors in which a higher fraction of the workforce is not able to work remotely experienced significantly greater declines in employment," and that "[1] ower-paid workers, especially female workers with young children, were significantly

146. See, e.g., Raga Justin, Texas Gov. Greg Abbott Says “There Is No Shutdown Coming” as Coronavirus Cases Surge, TEX. TRIB. (July 16, 2020, 8:00 PM), https://www.texastribune.org/2020/07/16/texas-shutdown-greg-abbott/ [https://perma.cc/5KE38DVE].

147. See, e.g., id.; Ga. Exec. Order No. 04.23.20.02, supra note 120 (“"Social Distancing” means keeping space between yourself and other people outside of your home or place of residence. Persons practicing Social Distancing should stay at least six (6) feet from other people, avoid assembling in groups, avoid crowded places, and avoid large crowds.").

148. Simon Mongey, Laura Pilossoph \& Alex Weinberg, Which Workers Bear the Burden of Social Distancing Policies? 7-11 (Nat'l Bureau of Econ. Rsch., Working Paper No. 27085, 2020), https://www.nber.org/papers/w27085.pdf [https://perma.cc/WQE2-FBCA].

149. Seung Jin Cho \& John V. Winters, The Distributional Impacts of Early Employment Losses from COVID-19, at 4, (Inst. of Lab. Econ., Discussion Paper No. 13266, 2020), http://ftp.iza.org/dp13266.pdf [https://perma.cc/2KAY-U4D3]. 
more affected by these disruptions." 150 Longstanding racial and gender discrimination in employment, segregation in job classifications, exploitation of immigrant workers, and the unequal distribution of family obligations are significant reasons for these disparities. ${ }^{151}$

Although members of socially subordinated groups have disproportionately paid the price for mitigation measures, they have been less able to reap the corresponding health benefits. Not everyone is able to comply with public health requirements and recommendations in ways that allow them to benefit from community mitigation. In particular, the personal responsibility strategy for COVID-19 has failed to protect low-wage workers deemed "essential," especially those who work in congregate and other highrisk settings. ${ }^{152}$ Because women, Black people, Indigenous people, Latinos, and Latinas are overrepresented among essential low-wage workers - again the result of longstanding discrimination and occupational segregation- the benefits of our pandemic response have had a significant and harmful gender and racial skew. ${ }^{153}$

150. Dimitris Papanikolaou \& Lawrence D.W. Schmidt, Working Remotely and the SupplySide Impact of COVID-19, at 22 (Nat'l Bureau of Econ. Rsch., Working Paper No. 27330, 2020), https://www.nber.org/papers/w27330.pdf [https://perma.cc/T5TZ-JG4Y].

151. See generally Connor Maxwell \& Danyelle Solomon, The Economic Fallout of the Coronavirus for People of Color, CTR. FOR AM. Progress (Apr. 14, 2020, 9:20 AM), https:/www.americanprogress.org/issues/race/news/2020/04/14/483125/economic-falloutcoronavirus-people-color/ [https://perma.cc/A3RD-GZGH] (discussing root causes of COVID-19's adverse economic efforts on communities of color).

152. See, e.g., Jim Vertuno, Grocery Workers Are Key During the Virus-and They're Afraid, NBC5 CHI. (Apr. 6, 2020, 10:31 AM), https://www.nbcchicago.com/news/coronavirus/groceryworkers-are-key-during-the-virus-and-theyre-afraid/2250687/ [https://perma.cc/7KW7-RSE5].

153. See generally COVID-19 in Racial and Ethnic Minority Groups, CTRS. FOR DISEASE CONTROL \& PREVENTION, https:/www.rtmsd.org/userfiles/270/My\%20Files/COVID19\%20in\%20Racial\%20and\%20Ethnic\%20Minority\%20Groups\%20_\%20CDC.pdf

[https://perma.cc/9G5A-2HFC] (Apr. 22, 2020) (noting that "[n]early a quarter of employed Hispanic and Black or African American workers are employed in service industry jobs compared to $16 \%$ of non-Hispanic whites"; and "Hispanic workers account for $17 \%$ of total employment but constitute $53 \%$ of agricultural workers; Black or African Americans make up 12\% of all employed workers, but account for $30 \%$ of licensed practical and licensed vocational nurses"); Hayley Brown, Shawn Fremstad \& Hye Jin Rho, Racial Inequality Among Workers in Frontline Industries: Black Workers Are Overrepresented and Undercompensated, CTR. FOR ECON. \& POL'Y RSCH. (June 4, 2020), https://cepr.net/racial-inequality-among-workers-in-frontlineindustries-black-workers-are-overrepresented-and-undercompensated/ [https://perma.cc/9UD5UUPU] ("[N] early three out of every ten (29.7 percent) Black workers work in one of six frontline industry groups, compared to just under one out of every five (19.2 percent) White workers."); id. ("[A]bout one-third of (33.2 percent) Black workers in frontline industries live in families with low incomes, compared to less than one-fifth (17.3 percent) of White workers."); Yearby \& Mohapatra, supra note 17 ("Ninety percent of home health care workers are women, and twothirds of them are women of color."); $i d$. ("Fifty-one-and-a-half percent of those who are 
Low-wage workers often perform jobs that cannot be done from home. ${ }^{154}$ They typically lack any financial cushion that would enable them to take unpaid leave. ${ }^{155}$ These workers thus find themselves forced to place themselves at risk. ${ }^{156}$ One recent study found that because "the initial economic consequences of the pandemic are particularly harmful to lowincome individuals," and those with higher incomes are more likely to be able to work remotely, "self-protective behaviors, such [as] social-distancing, are more practical, comfortable, and feasible for people with more income." 157 Moreover, many low-wage essential workers live in overcrowded housing, which they may share with others who are particularly vulnerable to COVID19. ${ }^{158}$ Crowded conditions make it virtually impossible to follow recommendations for self-isolation from at-risk household members. ${ }^{159}$ According to numerous observers, this dynamic has driven the alarmingly

considered frontline meatpacking workers are immigrants, compared with 17.0 percent of all workers in the US. In contrast, 19.1 percent of frontline meatpacking workers are white, compared to 63.5 percent of all workers.”).

154. Rachel Garfield, Matthew Rae, Gary Claxton \& Kendal Orgera, Double Jeopardy: Low Wage Workers at Risk for Health and Financial Implications of COVID-19, KAISER FAM. FOUND. (Apr. 29, 2020), https:/www.kff.org/coronavirus-covid-19/issue-brief/double-jeopardy-lowwage-workers-at-risk-for-health-and-financial-implications-of-covid-19/

[https://perma.cc/GV75-8FM3].

155. See id. (discussing low-wage workers' "precarious financial situations").

156. Id.

157. Nicholas W. Papageorge et al., Socio-Demographic Factors Associated with SelfProtecting Behavior During the COVID-19 Pandemic 3 (Inst. of Lab. Econ., Discussion Paper No. 13333, 2020), http://ftp.iza.org/dp13333.pdf [https://perma.cc/4CHZ-UVFE]. Another recent study made the striking finding that, even "in the depths of the lockdown" in Seattle, "weekly and daily cycles of travel consistent with commuting for work remain[ed] conspicuous among residents of less-educated neighborhoods and among individuals using reduced-fare public transit cards" - a finding the authors attributed to "the relative inability of less-educated and lowerincome people to work remotely." Rebecca Brough, Matthew Freedman \& David C. Phillips, Understanding Socioeconomic Disparities in Travel Behavior During the COVID-19 Pandemic 4 (Aug. 31, 2020) (unpublished manuscript), https://papers.ssrn.com/sol3/papers.cfm?abstract_id=3624920 [https://perma.cc/BY4H-3TX2].

158. See, e.g., Justin Feldman, Does COVID-19's Toll Reflect Social Inequality? Early Evidence from NYC, MEDIUM (Apr. 2, 2020), https://medium.com/@jmfeldman/does-covid-19stoll-reflect-social-inequality-early-evidence-from-nyc-209c3b0a0ff7 [https://perma.cc/ULS8ZAPF] (documenting a strong relationship between the per-capita rate of emergency department visits for influenza-like illness by zip code and the percentage of rental units where there is more than one occupant per room); Cuellar Mejia \& Cha, supra note 22.

159. Households Living in Close Quarters: How To Protect Those that Are Most Vulnerable, CTRS. FOR DISEASE CONTROL \& PREVENTION, https://www.cdc.gov/coronavirus/2019ncov/daily-life-coping/living-in-close-quarters.html [https://perma.cc/T5LM-7YZT] (Sept. 11, 2020). 
high rates of infection in many Black, ${ }^{160}$ Latino, ${ }^{161}$ and low-income communities. ${ }^{162}$ This, of course, reflects the legacy of residential segregation and policies that limit the availability of decent, affordable housing. ${ }^{163}$

In addition to being at higher risk of contracting SARS-CoV-2, Black people, Indigenous people, Latinos, and Latinas are at higher risk of severe illness and death due to COVID-19. ${ }^{164}$ Multiple factors could be contributing to these disparities, including exposure to higher doses of infectious particles in high-risk settings, disparate access to high-quality health care, and disparate treatment by health-care providers. ${ }^{165}$ Researchers have focused particularly on the fact that Black, Indigenous, Latino, and Latina patients are more likely to have underlying conditions - including diabetes, hypertension, and chronic lung and kidney disease - that predispose them to more severe COVID-19 illness and death. ${ }^{166}$ All of these factors are themselves

160. See, e.g., Rashawn Ray, Why Are Blacks Dying at Higher Rates from COVID-19?, BROOKINGS: FIXGOV (Apr. 9, 2020), https://www.brookings.edu/blog/fixgov/2020/04/09/whyare-blacks-dying-at-higher-rates-from-covid-19/ [https://perma.cc/67RS-W9QM].

161. See, e.g., Regina Garcia Cano, Anita Snow \& Bryan Anderson, COVID-19 Is Ravaging America's Vulnerable Latino Communities, GBH (June 21, 2020), https://www.wgbh.org/news/national-news/2020/06/21/covid-19-is-ravaging-americas-

vulnerable-latino-communities [https://perma.cc/XMN2-MTHH]; Usha Lee McFarling, When Hard Data Are 'Heartbreaking': Testing Blitz in San Francisco Shows Covid-19 Struck Mostly Low-Wage Workers, STAT (May 28, 2020), https:/www.statnews.com/2020/05/28/soberingfinding-covid19-struck-mostly-low-wage-essential-workers-san-francisco/

[https://perma.cc/9TGR-FV4N].

162. See, e.g., Garfield et al., supra note 154.

163. See, e.g., John C. Austin, COVID-19 Is Turning the Midwest's Long Legacy of Segregation Deadly, BrookIngs: THE Ave. (Apr. 17, 2020), https://www.brookings.edu/blog/the-avenue/2020/04/17/covid-19-is-turning-the-midwests-longlegacy-of-segregation-deadly/ [https://perma.cc/M9MF-R6EC].

164. Shanoor Seervai, Why Are More Black Americans Dying of COVID-19?, THE COMMONWEALTH FUND (June 20, 202), https://www.commonwealthfund.org/publications/podcast/2020/jun/why-are-more-blackamericans-dying-covid-19 [https://perma.cc/XN4V-64GW].

165. Id.

166. Id.; see Ctrs. For Disease Control \& Prevention, Table A-1. Selected Circulator Diseases Among Adults Aged 18 and over, By Selected Characteristics: UNITED STATES, 2018, at 3 tbl.A-1a https://ftp.cdc.gov/pub/Health_Statistics/NCHS/NHIS/SHS/2018_SHS_Table_A-1.pdf [https://perma.cc/96GM-YCAN] (reporting age-adjusted percentages of people with coronary heart disease, hypertension, and stroke among U.S. adults by race and ethnicity); CTRS. FOR Disease Control \& Prevention, Table A-2, Selected Respiratory Diseases Among Adults Aged 18 AND OVER, BY SElECTED CharActeristics: United StATES, 2018, at 3 tbl.A$2 \mathrm{a}$ (2018), https://ftp.cdc.gov/pub/Health_Statistics/NCHS/NHIS/SHS/2018_SHS_Table_A2.pdf [https://perma.cc/FX3C-G6VZ] (reporting age-adjusted percentages of people with emphysema, asthma, and chronic bronchitis among U.S. adults by race and ethnicity); CTRS. FOR Disease Control \& Prevention, National Diabetes Statistics Report 2020, at 4 fig.2 
significantly caused by a history of discrimination in employment, education, and health care, residential segregation, and other forms of social subordination. ${ }^{167}$ As Professor Angela Harris and her public-health-advocate collaborator, Aysha Pamukcu, recently argued, "Subordination based on markers of social stigma such as race, gender, sexuality, and class is chief among the structural forces creating unjust access to health-promoting opportunities and resources."168

Our response to the coronavirus pandemic has predictably exacerbated health disparities caused by structural racism and other forms of social subordination. It has done so precisely because it has focused on individual, rather than community, responsibility. In the next Part, we describe how the same focus on blame and responsibility that has shaped the community mitigation response to the pandemic is also deeply embedded in the employment and antidiscrimination laws that might have been used to cushion the blow, spread the costs more widely, and enable everyone to abide by and benefit from public health recommendations. As Harris and Pamukcu see it, the trouble with subordination is that it tends to be invisible. Americans tend to see individual agency and blameworthiness, rather than focusing on the institutional and structural context within which individuals make choices. ${ }^{169}$ Like Harris and Pamukcu, we see the influence of this individualistic bias in public health as well as in antidiscrimination law.

\section{ThE FAULT/RESPONSIBILITY PARADIGM AND THE LIMITS OF EMPLOYMENT AND ANTIDISCRIMINATION LAW}

Pandemic-preparedness plans pointed to the need for employment protections and income supports to ensure the success of community mitigation efforts. ${ }^{170}$ In this Part, we argue that instead of supporting public

(2020), https://www.cdc.gov/diabetes/pdfs/data/statistics/national-diabetes-statistics-report.pdf [https://perma.cc/B4WF-PUDL] (reporting age-adjusted estimated prevalence of diagnosed diabetes by race/ethnicity group and sex for U.S. adults); see also Donald J. Alcendor, Racial Disparities-Associated COVID-19 Mortality Among Minority Populations in the US, 9 J. CLINICAL MED. 2442 (2020), https://www.ncbi.nlm.nih.gov/pmc/articles/PMC7466083/ [https://perma.cc/R5T9-2BYW].

167. See generally Harris \& Pamukcu, supra note 31 (discussing "social determinants of health").

168. Id. at 762 .

169. Id. at 786.

170. See, e.g., Baum et al., supra note 2, at 10-11; Tong, supra note 110, at 225-26; Blake et al., supra note 113, at 216-17. Antidiscrimination protections and paid leave have frequently been discussed in the context of protections for people who are infected, but not for those seeking to shield themselves or their housemates from infection. See, e.g., BELLAGIO GRP., supra note 1 
health measures, longstanding rules of employment and antidiscrimination law have been significant contributors to the harms of the coronavirus pandemic - and can be expected to be even more significant as we move forward. The reason is that these bodies of law focus heavily on responsibility and fault —of both workers and employers. Legal actors worry about requiring employers to pay in the absence of fault or responsibility for the harms workers experience. At the same time, they worry that too much cushioning of workers' burdens will promote irresponsible conduct (which policymakers often call "moral hazard" ${ }^{171}$ ). They do so even when applying those employment and antidiscrimination doctrines that purport to abjure any inquiry into responsibility or fault.

The result is to undermine both the fairness and the effectiveness of public health measures. Employment and antidiscrimination law could provide a key source of protections and public supports to enable people to abide by public health recommendations and cope with resulting disruptions. As currently framed and applied, though, these areas of law are better poised to exacerbate a public health crisis than to mitigate it.

\section{A. The Failure To Ensure Safe Working Conditions and Compensate Workers for Harm}

Employment law frequently focuses on attributing responsibility or fault to the employer. It tries to relieve employers of having to bear costs for which they aren't deemed responsible. It does so by treating some costs or burdens as the fault or responsibility of the individual employee and by treating other costs or burdens as the responsibility of society in general. This is true not just of individual employment law but also of employment discrimination law. And it is true to a large extent even of those bodies of employment regulation that were designed as a move away from the fault-based paradigm of tort law.

This focus on responsibility or fault severely limits the protections that employment law provides. Those limits are particularly apparent in the application of the law to workers affected by the coronavirus pandemic. Both because an employee's particular vulnerability to COVID-19 is not

("Planning and response should facilitate public involvement in surveillance and reporting of possible cases without fear of discrimination, reprisal or uncompensated loss of livelihood. Recognizing their vulnerability, special efforts are needed to foster reporting by disadvantaged groups, as well as to protect them from negative impacts which could worsen their situation.").

171. For an important critique of the concept of "moral hazard," which informs our discussion throughout, see Tom Baker, On the Genealogy of Moral Hazard, 75 TEX. L. REV. 237 (1996). 
something the law treats as the employer's fault, and because the law aims to prevent the "moral hazard" of workers taking advantage of the system, the protections available to the most vulnerable workers are likely to be meager. The problem would not be so great if the law called upon the public at largethrough government programs financed by taxation- to cushion the blow. But it does not do so.

\section{Workplace Safety Regulation}

When governors across the country closed most businesses, they did so out of recognition that the workplace is likely to be a key locale in which SARS-CoV-2 can spread. ${ }^{172}$ Even as businesses have reopened, the significant risks remain. ${ }^{173}$ Certain types of workplaces - nursing homes, other congregate residential facilities, and meatpacking plants-have been especially notable for their contribution to the outbreaks we have experienced. ${ }^{174}$ Those businesses are, by and large, staffed by unusually

172. See, e.g., Minn. Exec. Order No. 20-04 (Mar. 16, 2020), https://www.leg.state.mn.us/archive/execorders/20-04.pdf [https://perma.cc/7NU8-VTJW] ("[P]ublic accommodations in which Minnesotans congregate pose a threat to the public health by providing environments for the spread of COVID-19."); Mich. Exec. Order No. 2020-09 (Rescinded) (Mar. 16, 2020), https://www.michigan.gov/whitmer/0,9309,7-387-90499_90705521789--,00.html [https://perma.cc/6V3P-ANCA] ("To mitigate the spread of COVID-19 . . it is reasonable and necessary to impose limited and temporary restrictions on the use of places of public accommodation," "mean[ing] a business . . of any kind . . . available to the public."); N.H. Exec. Order No. 2020-04 (Emergency Order No. 17) (Mar. 26, 2020), https://www.governor.nh.gov/sites/g/files/ehbemt336/files/documents/emergency-order-17.pdf [https://perma.cc/73VT-LZZS] (closing nonessential businesses to prevent community transfer); N.Y. Exec. Order No. 202.4 (Mar. 16, 2020), https://www.governor.ny.gov/news/no-2024continuing-temporary-suspension-and-modification-laws-relating-disaster-emergency

[https://perma.cc/LRQ7-556V]; N.J. Exec. Order No. 107 (Mar. 21 2020), https://nj.gov/infobank/eo/056murphy/pdf/EO-107.pdf [https://perma.cc/LCQ3-3JVM]; see also Safe Workplace for Essential Employers, CT.GOV, https://portal.ct.gov/DECD/Content/Coronavirus-Business-Recovery/Safe-Workplace-Rulesfor-Essential-Employers [https://perma.cc/H465-TP8C] ("Essential employees who are able to work from home SHOULD BE WORKING FROM HOME.”).

173. Rick Rojas \& Melina Delkic, As States Reopen, Governors Balance Existing Risks with New Ones, N.Y. TIMES (May 20, 2020), https:/www.nytimes.com/2020/05/17/us/coronavirusstates-reopen.html [https://perma.cc/C96B-8RB8].

174. See Waltenburg et al., supra note 16, at 887; Wallace et al., supra note 16, at 594-96; German Lopez, Why US Jails and Prisons Became Coronavirus Epicenters, Vox (Apr. 22, 2020, 12:50 PM), https:/www.vox.com/2020/4/22/21228146/coronavirus-pandemic-jails-prisonsepicenters [https://perma.cc/GHV5-TSFU]; Amy Maxmen, Coronavirus Is Spreading Under the Radar in US Homeless Shelters, NATURE (May 7, 2020), https://www.nature.com/articles/d41586-020-01389-3 [https://perma.cc/ZRM5-PD2E]; Eric Schlosser, America's Slaughterhouses Aren't Just Killing Animals, AtLANTIC (May 12, 2020), 
disempowered workers who must do their jobs in very close proximity to other people and often in unsanitary conditions. ${ }^{175}$

The continuing risks of workplace transmission create a number of issues. For one thing, what must employers do to protect their workers? This is a concern that might affect all workers - both those who are particularly vulnerable to COVID-19 due to age or chronic illness and those without such condition (who still face a significant risk of severe illness or death if infected). Does the employer have an obligation to ensure that social distancing measures, mask-wearing, or other procedures to reduce the spread of the virus are carried out in the workplace? And what must an employer do to ensure that those procedures do not place too great a burden on nonemployees (such as vendors or customers) who are especially at risk?

The area of law that is most relevant here is the body of workplace-safety regulation and particularly the federal Occupational Safety and Health Act (OSH Act). ${ }^{176}$ The OSH Act declares a federal "purpose and policy . . . to assure so far as possible every working man and woman in the Nation safe and healthful working conditions." 177 The statute requires employers to comply with standards issued by the Occupational Safety and Health Administration (OSHA). ${ }^{178}$ Through what is known as its "general duty" clause, the Act also imposes on each employer the obligation to "furnish to each of his employees employment and a place of employment which are free from recognized hazards that are causing or are likely to cause death or serious physical harm to his employees."179

Although these provisions could theoretically require employers to take meaningful steps to mitigate workplace transmission of SARS-CoV-2, there are several reasons to doubt they will be effective in that regard. One reason has to do with the difficult fit between the OSH Act's regime and the problems posed by communicable diseases. As Professor Paula Berg explains, OSHA "catapulted itself into a dominant position in this field when it interpreted its statutory obligation to regulate workplace toxins and hazardous conditions" during the height of the AIDS crisis "to include

\footnotetext{
https:/www.theatlantic.com/ideas/archive/2020/05/essentials-meatpeackingcoronavirus/611437/ [https://perma.cc/CU9W-7H8N]; Karen Yourish, K.K. Rebecca Lai, Danielle Ivory \& Mitch Smith, One-Third of All U.S. Coronavirus Deaths Are Nursing Home Residents or Workers, N.Y. TIMES (May 11, 2020), https:/www.nytimes.com/interactive/2020/05/09/us/coronavirus-cases-nursing-homes-us.html [https://perma.cc/5JDV-XVCP].

175. See supra text accompanying notes 154-163.

176. 29 U.S.C. $\$ \S 651-78$.

177. Id. $\S 651(\mathrm{~b})$.

178. $I d . \S 654(\mathrm{a})(2)$.

179. Id. $\S 654(\mathrm{a})(1)$.
} 
disease-causing microbes carried by human beings." 180 Though there is no doubt that the OSH Act's language reaches workplace health risks caused by communicable diseases, Berg is correct that the statutory scheme was crafted with other hazards in mind. Notably, the statute targeted "the increasing incidence of industrial accidents and work-related disease caused by nonhuman workplace hazards, specifically dangerous equipment, harmful physical agents, and toxic substances, many of which were associated with new technologies." 181 That history matters, because the risks associated with communicable disease "implicate[ ] a substantially broader and more complex constellation of rights and interests" than do "non-human workplace hazards." "182 Communicable diseases involve not just the balancing of workers' interests in protection against employers' economic costs and managerial prerogatives but also "the civil rights and liberties" of those who have, or are perceived to have, such diseases, as well as "the general public's right to be protected against an unreasonable risk of contagion." 183

The OSH Act's structure seems to mandate that employers favor the interests of employees over non-employees. ${ }^{184}$ The result may be to promote needless intrusions on the privacy interests of customers or vendors who are perceived to be at risk of transmitting the virus. ${ }^{185}$ Or it may even promote outright exclusion of those customers or vendors - even where the risk is in fact low. ${ }^{186}$ People with pre-existing conditions that make them particularly vulnerable - or make them seem to be particularly vulnerable - to COVID19 may thus face additional and unnecessary burdens. And, as we demonstrate below, the disability discrimination laws do not effectively shield those individuals from such burdens. ${ }^{187}$

But the statute is also unlikely to provide much protection to workers, even in those industries where transmission appears to be particularly likely. There

180. Paula E. Berg, When the Hazard Is Human: Irrationality, Inequity, and Unintended Consequences in Federal Regulation of Contagion, 75 WASH. U. L.Q. 1367, 1368-69 (1997).

181. Id. at 1370 (footnotes omitted).

182. Id. at 1371 .

183. Id. at 1371-72 (footnotes omitted).

184. See id. at 1391-92.

185. See id. at 1390-93 (noting that OSHA's bloodborne pathogens and tuberculosis standards intruded on the privacy interests of customers in order to protect workers, even though less intrusive approaches would have also ensured workplace safety).

186. See id. at 1391-93 (noting that OSHA's proposed tuberculosis standard encouraged employers to exclude customers or vendors with merely suspected TB).

187. See infra Part II.B.1. Indeed, the Supreme Court has interpreted the Americans with Disabilities Act to protect employers against liability when they rely on a federal safety regulation. See Albertson's, Inc. v. Kirkingburg, 527 U.S. 555, 577 (1999). The result is that OSHA regulations may affirmatively promote harm to workers, vendors, and customers whose disabilities make them vulnerable to COVID-19 infection. See Samuel R. Bagenstos, The Americans with Disabilities Act as Risk Regulation, 101 CoLUM. L. REV. 1479, 1506-07 (2001). 
are several reasons. For one thing, although OSHA has issued guidance on how employers should mitigate the risk of coronavirus transmission, ${ }^{188}$ along with interim enforcement guidance to its staff, ${ }^{189}$ it has not adopted any specific standards governing the steps employers should take to protect workers from SARS-CoV-2 infection-or infectious-disease risks generally. ${ }^{190}$ In the wake of the H1N1 influenza pandemic in 2009, the AFL$\mathrm{CIO}$ and several other labor organizations filed a petition with the agency for a standard protecting workers against infectious diseases. ${ }^{191}$ Although OSHA began the standards-setting process in response to that petition, the agency put the matter on the back burner in $2017 .{ }^{192}$ In response to the coronavirus pandemic, the AFL-CIO and National Nurses United asked the agency to adopt an "emergency temporary standard" addressing COVID-19. ${ }^{193}$ But

188. OCCUPATIONAL SAFETY \& HEALTH AdMIN., supra note 143.

189. Memorandum from Lee Anne Jillings, Acting Dir., Directorate of Tech. Support and Emergency Mgmt. \& Patrick J. Kapust, Acting Dir., Directorate of Enf't Programs to Reg'l Adm'rs \& State Plan Designees (May 19, 2020), https://www.osha.gov/memos/2020-0519/revised-enforcement-guidance-recording-cases-coronavirus-disease-2019-covid-19

[https://perma.cc/D98W-9SMQ] (providing an "updated interim guidance," effective May 26, 2020).

190. Scott D. Szymendera, Cong. Rsch. Serv., R46288, Occupational Safety and HEALTH AdMINISTRATION (OSHA): EMERGENCY TEMPORARY STANDARDS (ETS) AND COVID19, at 7 (2020), https://crsreports.congress.gov/product/pdf/R/R46288 [https://perma.cc/W92FL3ED] ("Currently, no OSHA standard directly covers exposure to airborne or aerosol diseases in the workplace.").

191. Unions Press OSHA To Enforce Swine Flu Protections (5/21), IndUS. SAFETY \& HyGIENE NEws (May 21, 2009), https://www.ishn.com/articles/88387-unions-press-osha-toenforce-swine-flu-protections-5-21 [https://perma.cc/6NJH-ANJN].

192. See Emily Schwing, How OSHA Has Failed To Protect America's Workers from COVID-19, GOV'T EXEC. (Apr. 7, 2020), https:/www.govexec.com/oversight/2020/04/howosha-has-failed-protect-americas-workers-covid-19/164382/ [https://perma.cc/T7JV-HFDL] (noting that the Obama Administration had begun "a formal regulatory effort" to set an infectious disease standard in 2010, but that the Trump Administration shelved the effort in 2017). Such long delays in the promulgation of standards are a persistent problem for the agency. For a general discussion of the problem, see Time Takes Its Toll: Delays in OSHA's Standard-Setting Process and the Impact on Worker Safety: Hearing Before the S. Comm. on Health, Educ., Lab. \& Pensions, 112th Cong. 725 (2012); see also John Howard, OSHA Standards-Setting: Past Glory, Present Reality and Future Hope, 14 EMP. RTS. \& EMP. POL'Y J. 237, 238 (2010) ("Using the Act's broad statutory authorities granted to the Secretary, OSHA adopted the majority of its current standards for toxic chemical and physical agents in the 1970s. The 1970s 'period of glory' passed quickly though. Beginning in early 1980s, the flow of OSHA health standards-setting slowed considerably. By 2010, the flow could charitably be described as a trickle.").

193. Letter from Richard L. Trumka, President, Am. Fed'n of Lab. \& Cong. of Indus. Orgs., to Eugene Scalia, Sec'y of Lab., U.S. Dep't of Lab. (Mar. 6, 2020), https://aflcio.org/sites/default/files/2020-03/FINAL\%20AFLCIO_Petition\%20COVID-19.pdf [https://perma.cc/K6YW-K7SW]; Letter from Bonnie Castillo, Exec. Dir., Nat'1 Nurses United, to Eugene Scalia, Sec'y of Lab., U.S. Dep't of Lab. \& Loren Sweatt, Principal Deputy Assistant 
OSHA still has not acted, and the D.C. Circuit denied mandamus to force it to act. ${ }^{194}$

The lack of a specific standard is a big deal because the enforcement of such standards is the principal means by which the agency can affect workplace practices. The OSH Act's general duty clause provides a residual mechanism to act in the absence of specific standards, but "courts have consistently held that standards are the preferred enforcement mechanism." 195 They thus impose a "heightened standard of proof" on the agency in general duty clause litigation. ${ }^{196}$ They require the agency to "prove the feasibility of abatement measures" for each targeted employer, one at a time. ${ }^{197}$ And they give employers ample opportunity, in each case, to "disput[e] the scientific basis" for the agency's action. ${ }^{198}$ These hurdles ensure that general duty clause litigation will be "initiated too infrequently to create long-lasting incentives." 199

Indeed, the Occupational Safety and Health Review Commission (OSHRC) - the administrative agency that adjudicates OSH Act violationshas recently expressed great skepticism about OSHA's reliance on the general duty clause. Rejecting a general duty claim involving the exposure of workers to dangerously excessive heat, the Commission offered its view that the clause "seems to have increasingly become more of a 'gotcha' and 'catch all' for the agency to utilize, which as a practical matter often leaves employers confused as to what is required of them." ${ }^{200}$ Referring to a prior case in which OSHA had relied on the general duty clause to challenge workplace exposure to a carcinogen, the Commission expressed a preference for the standard-setting process because "in a rulemaking proceeding, all interested parties have the opportunity to be heard, and a rule gives employers notice of what they must do to provide safe and healthful workplaces." 201

In a concurring opinion, then-Chair Heather MacDougall compared the case to others in which, she suggested, the agency had sought to "stretch" the

Sec'y of Lab. for Occupational Safety \& Health, Occupational Safety \& Health Admin. (Mar. 4, 2020), https://act.nationalnursesunited.org/page/-

/files/graphics/NNUPetitionOSHA03042020.pdf [https://perma.cc/HGQ6-R58H].

194. See In re Am. Fed'n of Lab. \& Cong. of Indus. Orgs., No. 20-1158, 2020 WL 3125324, at $* 1$ (D.C. Cir. June 11, 2020).

195. Reich v. Arcadian Corp., 110 F.3d 1192, 1199 (5th Cir. 1997).

196. Sidney A. Shapiro \& Randy Rabinowitz, Voluntary Regulatory Compliance in Theory and Practice: The Case of OSHA, 52 ADMIN. L. REV. 97, 134 n.184 (2000).

197. Id.

198. Id.

199. Id.

200. A.H. Sturgill Roofing, Inc., 2019 CCH OSHD 『 33,712 (No. 13-0224, 2019).

201. Id. (quoting Kastalon, Inc., 1986 CCH OSHD \ 27,643 (No. 79-5543, 1986)). 
general duty clause. ${ }^{202}$ And she said that employers cannot be expected, under that clause, to "analyz[e] personal risk factors" of particular employees. ${ }^{203} \mathrm{~A}$ "single employee's unique susceptibility to heat illness," she concluded, "cannot be sufficient to establish the existence of an 'excessive heat' hazard." 204 If that analysis were applied to workplace transmission of SARSCoV-2 - where different employees face different levels of risk based on their "idiosyncratic underlying health conditions" 205 - it would be very difficult for OSHA to deploy the general duty clause as a meaningful tool.

The problems with relying on the general duty clause are compounded by the severe resource constraints OSHA faces - constraints that have ensured that the OSH Act is massively underenforced. As the National Employment Law Project recently reported, OSHA "is not doing on-site enforcement and has no COVID-19-specific mandates for employers." 206 The agency "has a total of 862 inspectors to cover millions of workplaces"- the lowest number of inspectors in forty-five years. ${ }^{207}$ But even before the Trump Administration, scholars had long observed that " $[\mathrm{t}] \mathrm{he}$ combination of rare inspections and typically modest penalties creates a predictable incentive on the part of employers to ignore health and safety requirements that impose costs." 208

All told, the OSH Act is unlikely to provide effective protection against workplace risks of coronavirus infection-particularly for employees in the most vulnerable groups. And this is directly connected to the fault and responsibility focus of employment law generally. We can see the connection most directly in the application of the general duty clause, where the test for finding an employer violation looks a lot like a negligence standard. The D.C. Circuit recently described the governing law this way: "The General Duty Clause inquires not how an employer's accident rate compares with its own

202. See id. (MacDougall, Chairman, concurring) (first citing Mo. Basin Well Serv., Inc., 2018 CCH OSHD I 33,648 (No. 13-1817, 2018); then citing Mid S. Waffles, Inc., 2019 CCH OSHD I 33,708 (No. 13-1022, 2019) (MacDougall, Chairman, concurring); and then citing Pelron Corp., 1986 OSHD (CCH) $₫$ 27,605 (No. 82-388, 1986)).

203. Id.

204. Id.

205. Id. Note that, in Sturgill Roofing, the employee's "idiosyncratic" health conditions were hepatitis $\mathrm{C}$ and heart disease.

206. Deborah Berkowitz, Worker Safety in Crisis: The Cost of a Weakened OSHA, NAT'L EMP. L. PROJECT (Apr. 28, 2020), https://www.nelp.org/publication/worker-safety-crisis-costweakened-osha/ [https://perma.cc/UKM6-TXSZ].

207. Id.

208. Cynthia Estlund, Rebuilding the Law of the Workplace in an Era of Self-Regulation, 105 Colum. L. ReV. 319, 330 (2005); see also Christine Jolls, Law and the Labor Market, 2 ANN. REV. L. \& SOC. SCI. 359, 368 (2006) (noting that "[i]n light of the low financial penalties for the typical OSHA violation and the low likelihood of OSHA inspections, many have questioned whether OSHA is likely to have any effect on workplace safety at all" (citations omitted)). 
history or industry averages, but whether 'a reasonably prudent employer familiar with the circumstances of the industry would have protected against the hazard in the manner specified by the Secretary's citation." 209 The recent OSHRC decisions seeking to protect employers against "gotcha" applications of the clause also reflect an unwillingness to impose liability in the absence of fault. And former Chair MacDougall's suggestion that employers cannot be held liable for injuries related to the "personal risk factors" of individual workers similarly suggests a decision to allocate to those individual workers the responsibility for avoiding such injuries. ${ }^{210}$

Resistance to workplace safety regulation has long rested on the notion that it is up to individual workers to decide whether to avoid risky jobs. ${ }^{211}$ That resistance has led to the persistent underfunding of OSHA and the agency's many delays in issuing standards. Both at the level of doctrine and at the level of politics, then, the fault/responsibility paradigm has constrained occupational safety and health law in a way that makes it unlikely to protect workers who are particularly vulnerable to COVID-19.

\section{Workers' Compensation}

Many scholars who believe that the OSH Act tilts too far in favor of command-and-control regulation argue that workers' compensation gives employers an adequate incentive to optimize the risks their workplaces

209. BHC Nw. Psychiatric Hosp., LLC v. Sec’y of Lab., 951 F.3d 558, 565 (D.C. Cir. 2020) (quoting SeaWorld of Fla., LLC v. Perez, 748 F.3d 1202, 1207 (D.C. Cir. 2014)).

210. See A.H. Sturgill Roofing, Inc., 2019 CCH OSHD ף 33,712 (No. 13-0224, 2019) (MacDougall, Chairman, concurring).

211. See, e.g., Robert Kuttner, Everything for Sale: The Virtues and Limits of MARKETS 291 (Univ. of Chi. Press 1999) (1997) ("In the debates leading up to OSHA, industry representatives and their academic allies repeatedly made the argument that, if actual workers wanted higher levels of health and safety, their representatives would have made safety a higher priority in collective bargaining. . . . Therefore, it was professional do-gooders and not workers themselves who were agitating for unrealistically risk-free workplaces."). Proponents of marketbased solutions who favor deregulation assume that "[w]orkers will seek safer jobs unless employers compensate them for workplace risks." Sidney A. Shapiro, The Necessity of OSHA, 8 KAN. J.L. \& PUB. PoL'y 22, 23 (1999); see also W. KiP Viscusi, RisK BY ChOICE: Regulating HEALTH AND SAFETY IN THE WORKPLACE 1 (1983) ("These market-traded [workplace] risks are the result of individual choices ...."). For reasons to doubt that workers are actually in a position to negotiate efficient risk premiums - even if efficiency were our only goal here-see THOMAS O. McGarity \& Sidney A. Shapiro, Workers at Risk: The Failed Promise of the OcCupAtional SAFETy AND HEAlth AdMinistration 18-20 (1993) and Alison Morantz et al., Economic Incentives in Workers' Compensation: A Holistic, International Perspective, 69 RUTGERS U. L. REV. 1015, 1021-22, 1032-35 (2017). 
impose on employees. ${ }^{212}$ One might, therefore, expect workers' compensation to solve the problem even if direct regulation does not.

But workers' compensation does a notoriously poor job of responding to diseases (as opposed to injuries) linked to the workplace. One leading review finds "no question that most occupational diseases are never compensated" under the program. ${ }^{213}$ Studies show that only a relatively small percentage of workers with occupational diseases receive compensation-although estimates of the percentage vary. ${ }^{214}$ Cases in which a workplace exposure arguably aggravated an employee's "preexisting health conditions"—as, for example, when a worker with diabetes faces an elevated risk of developing a severe case of COVID-19-face significant barriers to coverage and payment under state workers' compensation systems. ${ }^{215}$

The reasons stem from the application of "[ $\mathrm{t}]$ he central test for determining compensability in workers' compensation": The injury or illness must be one "arising out of and in the course of employment." ${ }^{216}$ It may be difficult for employees to show that they contracted a disease at work- "particularly when the disease also commonly occurs outside workplaces." ${ }^{217}$ And recent changes to workers' compensation laws in many states have made the problem worse. Where employers were once required to take employees "as they found them," workers are increasingly required "to demonstrate that the workplace event was the 'major contributing cause' or the 'predominant cause' - or equivalent language - of the disability." 218 These rules will pose major barriers to those who develop COVID-19. Those workers will be required to prove that they acquired the disease at the workplace, and that some pre-existing condition was not the major cause for the seriousness of their illness.

Once again, this result stems directly from the fault/responsibility paradigm that drives employment law rules. This may seem a bit surprising. After all, the "grand bargain" of workers' compensation was supposed to remove fault from the equation. The whole point was to compensate for the

212. See, e.g., Michael J. MoORE \& W. KiP Viscusi, COMPENSATION MECHANiSMS For Job Risks: WAGES, Workers' COMPENSATION, AND PRODUCT Liability 3 (1990).

213. See Emily A. Spieler \& John F. Burton Jr., The Lack of Correspondence Between WorkRelated Disability and Receipt of Workers' Compensation Benefits, 55 AM. J. INDUS. MED. 487, 499 (2012).

214. See id. at 493.

215. See Emily A. Spieler, (Re)assessing the Grand Bargain: Compensation for Work Injuries in the United States, 1900-2017, 69 RUTGERS U. L. REV. 891, 997 (2017).

216. Martha T. McCluskey, The Illusion of Efficiency in Workers ' Compensation "Reform," 50 RutGers L. REV. 657, 792 (1998).

217. See Spieler \& Burton, supra note 213, at 499.

218. Spieler, supra note 215 , at 938. 
"[m]any accidents" that "seemed to come from the inherent dangers of work" - accidents for which "fault could not easily be assigned to either the worker or employer." "219 In exchange for limitations on the amount of recovery, "employees are covered for all workplace injuries without having to prove employer fault." 220

Yet considerations of fault - on both the employer's and the worker's part-creep back into the application of the system. Some states provide explicit exclusions for accidents caused by worker misconduct. ${ }^{221}$ The more insidious invasion of fault, though, has occurred in the "arising out of and in the course of" requirement. Reforms that have been designed to tighten up that requirement appear on their face to rest on empirical judgments about causation — on an effort to limit employers' responsibility for those injuries that were "really" caused by the workplace. However, "[c] ausation is not simply a matter of fact, but is a complex social construction shaped by political views." 222 Because "[a]ny injury or illness is an interaction between a work environment and a human body (and mind) with the outcome dependent on the characteristics of both," the question of what illnesses we treat as caused by the workplace "is not simply a question of science but of distributive values."223

As Professor Martha McCluskey extensively demonstrates, the reforms that tightened the "arising out of and in the course of" requirement ultimately rest on a "fault-like focus on workers as causes of injury." 224 These reforms

219. Price V. Fishback \& Shawn Everett Kantor, A Prelude to the Welfare State: The ORIGINS OF WORKERS' COMPENSATION 3 (2000); see JOHN FABIAN WiTt, THE ACCIDENTAL REPUBLIC 126 (2004) (describing the essence of workers' compensation as follows: "The fault of the employer, the employee, or some fellow employee would be irrelevant, except where an employee injured himself by his own intentional wrongful act"). Some commentators have long recognized that the asserted rejection of fault-based liability in workers' compensation is more rhetoric than reality. See Lawrence M. Friedman \& Jack Ladinsky, Social Change and the Law of Industrial Accidents, 67 ColuM. L. REV. 50, 71 (1967) ("In essence, then, workmen's compensation was designed to replace a highly unsatisfactory system with a rational, actuarial one. It should not be viewed as the replacement of a fault-oriented compensation system with one unconcerned with fault. It should not be viewed as a victory of employees over employers."). But the canonical story remains that the program adopts a no-fault system.

220. Matthew T. Bodie, Employment as Fiduciary Relationship, 105 GEO. L.J. 819, 838 (2017).

221. See id. at 838 n. 120.

222. McCluskey, supra note 216, at 794; see also MORTON J. HoRwITZ, THE TRANSFORMATION OF AMERICAN LAW 1870-1960: THE CRISIS OF LEGAL ORTHODOXY 53 (1992) ("[B]ecause judges and jurists inevitably imported moral ideas into their determinations of legal causation, they were making discretionary policy determinations under the guise of doing science.").

223. McCluskey, supra note 216, at 795-96.

224. Id. at 799. On the connection between determinations of causation and of fault in tort and workers' compensation law, see WITT, supra note 219, at 168-70. 
sought "to reduce claimant moral hazard by restricting compensation for losses perceived to result primarily from cost-increasing by workers rather than from workplace harms or actual disability." 225 They aimed to "weed[ ] out claims for injuries to which workers' lifestyle, skill levels, leisure activities, age, preexisting health conditions, or job choice may have contributed"; as a result, they effectively "reintroduce employers' nineteenthcentury fault-based defenses of contributory negligence and assumption of risk, to some extent." ${ }^{226}$ But these rules do not eliminate moral hazard so much as "redistribut[e]" it to employers, who can pass off the costs of accidents on workers or society at large. ${ }^{227}$

\section{Title VII}

Title VII of the Civil Rights Act of 1964 protects workers against race discrimination by their employers. ${ }^{228}$ It is not common to think of Title VII as a workplace safety statute. ${ }^{229}$ But there seems to be a strong reason to believe that some jobs that present especially significant risks of coronavirus infection are disproportionately held by women and people of color. As Ruqaiijah Yearby and Seema Mohapatra show, some of the workers at greatest risk are "those working in home health care and in the meat processing industry." ${ }^{230}$ Fully "[n]inety percent of home health care workers are women, and two-thirds of them are women of color." ${ }^{231}$ And "[m]ore than half of workers in the US who work in meat processing are people of color"-

225. Martha T. McCluskey, Efficiency and Social Citizenship: Challenging the Neoliberal Attack on the Welfare State, 78 IND. L.J. 783, 851 (2003). As Witt shows, similar concerns drove initial opposition to the adoption of workers' compensation schemes. See WITT, supra note 219, at 172 .

226. McCluskey, supra note 225 , at 851.

227. Id. at 853. Here, McCluskey's argument follows that of the early twentieth-century Legal Realists. See Bagenstos, supra note 56, at 422-29. For an example of case law influenced by the Legal Realists on this point, see W. Coast Hotel Co. v. Parrish, 300 U.S. 379, 399 (1937) ("The exploitation of a class of workers who are in an unequal position with respect to bargaining power and are thus relatively defenseless against the denial of a living wage is not only detrimental to their health and well being, but casts a direct burden for their support upon the community. What these workers lose in wages the taxpayers are called upon to pay.").

228. See 42 U.S.C. $§ 2000$ e-2(a).

229. Claims that an employer intentionally assigned workers to more dangerous jobs based on their race are not, of course, unheard of. See, e.g., Slack v. Havens, No. 72-59-GT, 1973 WL 339, at *1 (S.D. Cal. May 15, 1973) (employer assigned Black employees to "hard and dangerous" tasks from which it excused similarly situated white employees), aff'd and remanded, 522 F.2d 1091 (9th Cir. 1975).

230. Yearby \& Mohapatra, supra note 17.

231. Id. 
most of whom are immigrants. ${ }^{232}$ If people in these vulnerable positions must work in unsafe conditions or are denied adequate personal protective equipment - both of which seem to be the case in many workplaces ${ }^{233}$ might Title VII be a basis for them to force their employers to respond?

Unfortunately, there are substantial barriers to successful Title VII litigation in this context. And these barriers stem from the same individualistic fault/responsibility paradigm. ${ }^{234}$ Unless workers can show that the racial or gender composition of an especially risky job classification results from intentional discrimination by a particular employer, they will be unable to establish disparate-treatment discrimination. ${ }^{235}$ If that composition results from broader forms of systemic social subordination, courts are unlikely to conclude that the employer discriminated vis-à-vis a similarly situated comparator. ${ }^{236}$ They will instead determine that society at largerather than any particular employer-is responsible for any disparity that results. ${ }^{237}$

A similar problem is likely to confront disparate-impact litigation. One might argue that, given the disproportionate representation of people of color in some high-risk jobs, unsafe conditions in those jobs necessarily cause a disparate impact on the basis of race. Absent a selection criterion that disproportionately directs members of certain racial or ethnic groups into those jobs, however, courts will say that the employer did not "use[ ] a

\section{Id.}

233. See, e.g., id. For recent litigation involving conditions in meatpacking facilities, see Notice of Removal, Benjamin v. JBS S.A., No. 2:20-cv-02594 (E.D. Pa. June 2, 2020), 2020 WL 2893505; Plaintiff's Original Petition, Parra v. Quality Sausage Co., No. DC-20-06406 (Dist. Ct. Tex. Apr. 30, 2020), 2020 WL 2231332; Rural Cmty. Workers All. v. Smithfield Foods, Inc., 459 F. Supp. 3d 1228, 1240-41 (W.D. Mo. 2020). For recent litigation involving farmworkers, see Castillo v. Whitmer, 823 F. App'x 413 (6th Cir. 2020).

234. See Harris \& Pamukcu, supra note 31, at 788-89 (discussing the "individualist bias" evident in judicial interpretations of Title VII).

235. See, e.g., Ricci v. DeStefano, 557 U.S. 557, 577 (2009) ("Disparate-treatment cases present 'the most easily understood type of discrimination,' and occur where an employer has 'treated [a] particular person less favorably than others because of' a protected trait. A disparatetreatment plaintiff must establish 'that the defendant had a discriminatory intent or motive' for taking a job-related action." (citations omitted)).

236. Compare Slack v. Havens, No. 72-59-GT, 1973 WL 339, at *1 (S.D. Cal. May 15, 1973), aff'd and remanded, 522 F.2d 1091 (9th Cir. 1975), in which the employer treated similarly situated Black and white employees differently. See generally Charles A. Sullivan, The Phoenix from the Ash: Proving Discrimination by Comparators, 60 ALA. L. REV. 191, 193 (2009) ("The reality on the ground is that discrimination cases today increasingly turn not on whether the plaintiff has proven her prima facie case or established that the 'legitimate nondiscriminatory reason' is a pretext for discrimination (although the courts continue to invoke the McDonnell Douglas mantra), but rather on whether the plaintiff has identified a suitable 'comparator' who was treated more favorably than she.").

237. See Bagenstos, Structural Turn, supra note 57, at 43-45. 
particular employment practice that cause[d] a disparate impact" as required for liability under the statute. ${ }^{238}$ Again, the courts will effectively determine that any disparities are the responsibility of society, not the particular employer. And even if workers could show that the employer was responsible for a disparate impact, the employer would still escape liability if it could show that the challenged practice was "job related" and "consistent with business necessity." ${ }^{239}$ Where a practice leads to demonstrable cost savings, courts tend to say that the business-necessity test is satisfied. ${ }^{240}$ This doctrine, too, rests on the premise that employers are responsible for their own enterprises' success, and that requiring them to assume too great a cost burden improperly forces them to shoulder a burden that society in general should bear. ${ }^{241}$

\section{B. The Failure To Protect Those Who Cannot or Should Not Work}

Some workers should stay home. Some should stay home for short durations while they pose a risk of infection to others. Others should stay home for longer durations because it is not safe for them to work or because they have obligations to care for others. If the law does not ensure that those individuals can stay home while receiving pay and benefits, they will face a deadly dilemma - unable to work without risking life and health, but unable to avoid work without risking their livelihood and health insurance. Unfortunately, the law does not provide these protections.

\section{The ADA and FMLA}

If it is temporarily unsafe for an employee to work due to age or chronic conditions that make them particularly vulnerable to COVID-19, a paid leave would provide a way out of the deadly dilemma. A temporary paid leave for individuals who are likely to transmit SARS-CoV-2 during the period of recommended quarantine and isolation could also help protect coworkers, customers, and the communities in which they live. And paid caregiving leave would assist those whose family members or dependents are

238. 42 U.S.C. $§ 2000 \mathrm{e}-2(\mathrm{k})(1)(\mathrm{A})(\mathrm{i})$. Disparate impact litigation under Title VII has generally been successful only in challenges to job selection criteria. See Bagenstos, Structural Turn, supra note 57, at 23-24; Michael Selmi, Was the Disparate Impact Theory a Mistake?, 53 UCLA L. REV. 701, 733-34 (2006).

239. $\S 2000 \mathrm{e}-2(\mathrm{k})(1)(\mathrm{A})(\mathrm{i})$.

240. See, e.g., International Brotherhood of Electrical Workers Local 605 v. Miss. Power \& Light Co., 442 F.3d 313, 319 (5th Cir. 2006).

241. See Bagenstos, Structural Turn, supra note 57, at 43-45. 
particularly vulnerable or are forced to stay home from school or child care due to public health mitigation measures.

Although there are two general federal statutes that require employers to provide leave related to health conditions in some circumstances, they do not solve the problem - both because their coverage is limited and because they do not mandate paid leave. A few states require employers to provide paid sick leave, but coverage is limited even there. And Congress created a special COVID-19 paid leave program in the Families First Coronavirus Response Act, but the program is merely temporary and leaves out around half of affected workers.

Begin with the general federal statutes: the Americans with Disabilities Act (ADA) and the Family and Medical Leave Act (FMLA). The ADA mandates that employers provide "reasonable accommodations to the known physical or mental limitations of an otherwise qualified individual with a disability who is an applicant or employee, unless such covered entity can demonstrate that the accommodation would impose an undue hardship on the operation of the business." 242 The lower federal courts have repeatedly recognized that granting "some amount of leave" to a disabled employee "may be a reasonable accommodation, at least in some circumstances." 243 Because virtually any underlying health impairment that results in a risk of acquiring a deadly disease will constitute a protected "disability" under the ADA Amendments Act, ${ }^{244}$ the ADA's accommodation requirement looks initially promising as a source of a right to temporary leave for those workers who are most at risk. ${ }^{245}$

242. 42 U.S.C. $\S 12112(\mathrm{~b})(5)(A)$.

243. Stacy A. Hickox \& Joseph M. Guzman, Leave as an Accommodation: When Is Enough, Enough?, 62 CLEV. ST. L. REV. 437, 444 (2014).

244. See ADA Amendments Act of 2008, Pub. L. 110-325, sec. 4, § 3, 122 Stat. 3553, 3555 (2008) (codified as amended in scattered sections of titles 29 and 42 U.S.C.).

245. The accommodation requirement could also provide leverage for especially vulnerable workers to force their employers to provide them safer conditions - whether by providing them special protective equipment, by changing work schedules to avoid times of contact with others, by allowing them to work from home, by transferring them to less risky positions, or otherwise, so long as the accommodation does not impose an undue hardship. See 42 U.S.C. § 12111(9)(B) (defining the term "reasonable accommodation" to include, inter alia, "job restructuring, parttime or modified work schedules, reassignment to a vacant position, [and] acquisition or modification of equipment or devices"). Although early post-ADA decisions seemed to rule out work-from-home accommodations, recent cases have expressed more willingness to find them reasonable. See, e.g., Bilinsky v. Am. Airlines, Inc., 928 F.3d 565, 573 (7th Cir. 2019). For a concrete discussion of what accommodations like this might look like in response to COVID-19, see Samuel Bagenstos, Accommodating Medical Professionals with Pre-Existing Health Conditions in the Coronavirus Pandemic, JusT SEC. (May 7, 2020), https://www.justsecurity.org/70050/accommodating-medical-professionals-with-pre-existinghealth-conditions-in-the-coronavirus-pandemic/ [https://perma.cc/6KS4-EGPE]. 
But there are three key problems with relying on the ADA here. First, the statute's accommodation requirement is limited to disabilities of the employee. ${ }^{246}$ To the extent that a worker seeks leave or other accommodations because of the particular vulnerability of a spouse or child, the ADA will provide no remedy. The statute prohibits employers from "excluding or otherwise denying equal jobs or benefits to a qualified individual because of the known disability of an individual with whom the qualified individual is known to have a relationship or association." 247 But that prohibition on associational discrimination has been held not to require accommodation of a nondisabled employee based on that employee's association with an individual with a disability. ${ }^{248}$

The second problem is even more significant. Although courts have recognized in general that leave can be a reasonable accommodation, they have resisted requiring employers to provide leaves of absence that are indefinite or too long (though they have mostly been unclear as to how long is too long). ${ }^{249} \mathrm{~A}$ recent decision by the Seventh Circuit, for example, recognized that "[i]ntermittent time off or a short leave of absence-say, a couple of days or even a couple of weeks-may, in appropriate circumstances, be" a reasonable accommodation. ${ }^{250}$ The court went on to say, however, that the ADA could not be read to require "a medical leave spanning multiple months." 251

And the third problem is the most important of all. Even where the ADA requires an employer to provide leave to a worker with a disability, it will require only unpaid leave. ${ }^{252}$ If we want to ensure that individuals are not put to the dilemma of risking their lives and health by going to work, or risking their livelihoods and health insurance by staying home, paid leave is necessary. As it has been interpreted by the EEOC and the courts, the ADA simply does not address the problem.

These limitations stem directly from the fault/responsibility paradigm. As one of us has shown, the EEOC and the courts have long interpreted the

246. 42 U.S.C. $\S 12111(8)$.

247. Id. $\S 12112(\mathrm{~b})(4)$.

248. See, e.g., Den Hartog v. Wasatch Acad., 129 F.3d 1076, 1084-85 (10th Cir. 1997); see also Lawrence D. Rosenthal, Association Discrimination Under the Americans with Disabilities Act: Another Uphill Battle for Potential ADA Plaintiffs, 22 Hofstra LAB. \& EMP. L.J. 132, 169 (2004) ("Although the ADA requires employers to accommodate individuals with disabilities as long as such an accommodation would not present an undue hardship on the employer, the association provision of the ADA has no such requirement.") (footnotes omitted)).

249. See Hickox \& Guzman, supra note 243, at 452-63.

250. Severson v. Heartland Woodcraft, Inc., 872 F.3d 476, 481 (7th Cir. 2017).

251. $I d$.

252. See, e.g., Molly Weston Williamson, The Meaning of Leave: Understanding Workplace Leave Rights, 22 N.Y.U. J. LeGIS. \& PUB. POL’y 197, 254 (2019). 
ADA's open-ended "reasonable accommodation" language in a way that protects employers against being forced to engage in "ad hoc wealth redistribution to individuals with disabilities." 253 The courts have especially sought to protect businesses against being forced "to bear a financial burden not because of any particular fault on [their] part, but simply because of the fortuity that this particular worker with a disability applied for one of [their] positions." ${ }^{254}$ The refusal to require employers to provide extended or paid leaves rests on the same understanding that individual firms "can be held responsible for their 'own' choices but cannot be required to make up for broader failures of social provision." 255

The FMLA plainly requires covered employers to provide covered workers with twelve weeks' leave for their own or their family members' "serious health condition[s]." ${ }^{256}$ But the statute covers only relatively large employers (those with fifty or more employees), ${ }^{257}$ and it covers only those employees who have worked for their current employers for at least twelve months and for at least 1,250 hours during that period. ${ }^{258}$ These limitations deny FMLA protections to approximately $44 \%$ of private-sector employees ${ }^{259}$ —not to mention those workers who are classified as independent contractors. And even where it does apply, the statute requires employers to grant only unpaid leave. ${ }^{260}$ Like the ADA, then, the FMLA continues to leave vulnerable workers on the horns of a deadly dilemma. ${ }^{261}$

Congress seemed to recognize the need for leave when it adopted the Families First Coronavirus Response Act (FFCRA). ${ }^{262}$ That statute added a

253. See Bagenstos, Future of Disability Law, supra note 57, at 52.

254. Id.

255. Id. at 53.

256. 29 U.S.C. $\S 2612(\mathrm{a})(1)(\mathrm{C})-(\mathrm{D})$.

257. Id. $\S 2611(4)(\mathrm{A})(\mathrm{i})$.

258. Id. $\S 2611(2)(\mathrm{A})$.

259. Helene Jorgensen \& EILEen ApPelbaum, Expanding Federal Family and

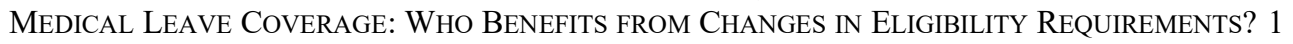
(2014), https://cepr.net/documents/fmla-eligibility-2014-01.pdf [https://perma.cc/U5ZP-SXT4].

260. See, e.g., Samuel R. Bagenstos, Nevada Department of Human Resources v. Hibbs: Universalism and Reproductive Justice, in REPRODUCTIVE RIGHTS AND JUSTICE STORIES (Melissa Murray, Kate Shaw \& Reva Siegel eds., 2019) (highlighting the lack of an entitlement to paid leave as a significant limitation of the FMLA).

261. A handful of states and localities have adopted paid family or sick leave requirements. See generally Paid Family and Sick Leave in the U.S., KAISER FAM. FOUND. (Jan. 28, 2020), https://www.kff.org/womens-health-policy/fact-sheet/paid-family-leave-and-sick-days-in-the-u$\mathrm{s} /[\mathrm{https}: / /$ perma.cc/H3CQ-QRLP]. Even in jurisdictions where these mandates exist, however, their coverage is sufficiently uneven (and the number of required leave days sufficiently small) that they are no substitute for a meaningful federal leave mandate in response to a threat like the coronavirus.

262. Families First Coronavirus Response Act, Pub. L. No. 116-127, 134 Stat. 178 (2020). 
temporary mandate that employers provide paid leave in a variety of circumstances: two weeks' fully paid leave to employees who are unable to work because they are quarantined or have COVID-19 symptoms, two weeks' leave at two-thirds of the worker's normal rate of pay to employees who must care for individuals who are quarantined or have COVID-19 symptoms, and twelve weeks' leave at two-thirds of the worker's normal rate of pay to employees who must care for children whose schools or child care providers are closed due to the pandemic. ${ }^{263}$ Employers were to be compensated with dollar-for-dollar tax credits. ${ }^{264}$ But that mandate expired at the end of 2020 - though Congress extended the tax credit through March of 2021 for those employers who decided voluntarily to continue to provide leave. ${ }^{265}$ And "a majority of the workforce [wa]sn't eligible for the benefits" in any event, because Congress and the Trump Administration exempted employees for both large and small employers, as well as many front-line workers. ${ }^{266}$ Two researchers for the Kaiser Family Foundation concluded that the limitations on the receipt of paid leave under the FFCRA will impose a disproportionate burden on already-disempowered employees: Fully $75 \%$ of the potentially excluded workers are women, 39\% are people of color, and " $18 \%$ are low-wage, for whom having to take unpaid leave when they are sick could put them in a difficult financial situation." 267

263. See id. $\S 5102(a), 134$ Stat. at 195-96.

264. See id. $\S 7001,134$ Stat. at 210-12; id. § 7003, 134 Stat. at 214-17.

265. See Evandro Gigante, Harris Mufson, Alex Downie \& Abigail Rosenblum, Congress Extends FFCRA Tax Credit into 2021, Declines to Extend FFCRA Leave, LAW \& THE WORKPLACE (Dec. 28, 2020), https://www.lawandtheworkplace.com/2020/12/congress-extendsffcra-tax-credit-into-2021-declines-to-extend-ffcra-leave/ [https://perma.cc/2JQ4-X9QM].

266. Ben Penn, Paid-Leave Promise Turns 'Mirage' for Most Workers in Pandemic, BloOMBerg L. (May 27, 2020, 3:01 AM), https://news.bloomberglaw.com/daily-laborreport/paid-leave-promise-turns-mirage-for-most-workers-in-pandemic?context=article-related [https://perma.cc/R8M9-Q7LQ]; see Michelle Long \& Matthew Rae, Gaps in the Emergency Paid Sick Leave Law for Health Care Workers, KAISER FAM. FOUND. (June 17, 2020), https://www.kff.org/coronavirus-covid-19/issue-brief/gaps-in-emergency-paid-sick-leave-lawfor-health-care-workers/ [https://perma.cc/5LPT-TZST] (estimating "that at least 69.4 million workers, or approximately four in ten workers, are potentially ineligible for emergency paid sick leave benefits"). For the specific provisions limiting availability, see $\S 110(\mathrm{a})(3)(\mathrm{B}), 134$ Stat. at 190; id. §5110(2)(b)(i)(I), 134 Stat. at 199; id. § 5111(1)-(2), 134 Stat. at 201; Coronavirus Aid, Relief, and Economic Security (CARES) Act, Pub. L. No. 116-136, § 1110(a)(2), 134 Stat. 181, 306-07 (2020); Paid Leave Under the Families First Coronavirus Response Act, 80 Fed. Reg. 19326 (proposed Apr. 2, 2020) (to be codified at 29 C.F.R. pt. 826).

267. Long \& Rae, supra note 266 (footnote omitted). 


\section{Unemployment and Disability Insurance}

If people cannot or should not work because of their illness or their particular vulnerability to illness, and if it is not fair to employers to make them pay, it seems straightforward to socialize the cost, so that the burdens of mitigation measures are shared by those who benefit from those measures. Yet the relevant government programs do not do this. Again, this result stems from concern about fault and responsibility. Here, as with workers' compensation law, that concern is instantiated as a fear of workers' "moral hazard."

\section{a. Unemployment Insurance}

Unemployment insurance (UI) is our nation's primary means of protecting workers against the harshest consequences of temporary economic downturns. ${ }^{268}$ That program could, in theory, serve as the best protection against the deadly dilemma described above by offering vulnerable "workers, particularly low-wage workers, a viable alternative to being compelled to work in a pandemic." ${ }^{269}$ But several crucial aspects of the unemployment insurance system limit its effectiveness as a protection in this context.

When it set up the system in the Social Security Act of 1935, Congress deferred to older notions of federalism and provided that states should administer the program. ${ }^{270}$ It gave individual states broad discretion to set benefits above a very low federal floor. ${ }^{271}$ Employers finance the system through "experience rated" premiums - the more claims are accepted against a particular employer, the more that employer will be forced to pay to insure its workers in the future. ${ }^{272}$ "To access UI, workers must meet state-specific monetary eligibility requirements (based on prior earnings), meet non-

268. See Jerry L. Mashaw, Unemployment Compensation: Continuity, Change, and the Prospects for Reform, 29 U. MICH. J.L. REFORM 1, 2 (1996) ("Today's unemployment compensation system was designed as the answer to a particular question-how to maintain income security and consumer purchasing power during economically induced short-term unemployment.").

269. Wesley Bignell \& Marshall Steinbaum, A Way To Help Workers, Now and in the Future, AM. ProsPeCt (May 28, 2020), https://prospect.org/coronavirus/a-way-to-help-workers-nowand-in-the-future/ [https://perma.cc/2P3Y-UT69].

270. See Daniel N. Price, Unemployment Insurance, Then and Now, 1935-85, SoC. SEC. Bull., Oct. 1985, at 23-24.

271. See Gillian Lester, Unemployment Insurance and Wealth Redistribution, 49 UCLA L. REV. 335, 344 (2001).

272. Id. at $344-45$. 
monetary requirements (based on the nature of an employment separation and availability for future work) and navigate complex state bureaucracies." 273

The structure of the program thus creates multiple incentives to shortchange workers. To avoid high taxes that might drive businesses to less generous jurisdictions, states have an incentive to reduce benefits. ${ }^{274}$ In part for this reason, "most American workers are residents of states with frail UI systems and declining social protection." ${ }^{275}$ And employers have an incentive to fight their workers' claims and otherwise engage in "lawyering and innovations in business processes that make benefits awards less likely," so that they may avoid higher premiums in the future. ${ }^{276}$

The results have been predictable. States have imposed significant hurdles to obtaining unemployment benefits in recent years. The Center for American Progress reported in 2016 that "a growing number of states are disregarding their obligations to operate fair and accessible UI programs, often by constructing complex automated claims-filing systems and overly stringent documentation requirements" - with the effect of "discouraging eligible workers from initially applying for the benefits they have already earned" and

273. H. Luke Shaefer, Identifying Key Barriers to Unemployment Insurance for Disadvantaged Workers in the United States, 39 J. Soc. POL'y 439, 439 (2010).

274. See Brian Galle, How To Save Unemployment Insurance, 50 ARIZ. ST. L.J. 1009, 1031 (2018) ("The result is a race to the bottom. States that aim to offer generous UI benefits must fund them, and risk driving out employers, triggering unemployment, which must be funded through higher taxes on the remaining businesses." (footnote omitted)); Lester, supra note 271, at 356 n.85 ("Interstate variation creates unfairness as well as a potential 'race to the bottom' as states may succumb to competition for corporate investment by making UI obligations increasingly less onerous for employers."); Mashaw, supra note 268, at 10 ("[I]t is difficult, to say the least, for states to move too far out in front of their fellow states whose response might be, not to follow their lead, but to attempt to attract their industries."); WILL KIMBALL \& RICK MCHUGH, How LOW Can We Go? State Unemployment Insurance Programs Exclude Record Numbers of JOBLESS WORKERS 12 (2015), https://www.epi.org/files/2015/how-low-can-we-go-stateunemployment-r3.pdf [https://perma.cc/EH2J-LLVU] ("Permitting states to operate restrictive UI programs undercuts the goals of UI and creates competitive pressures on those states with decent programs to engage in a 'race to the bottom."').

275. Chang Yu-Ling, Unequal Social Protection Under the Federalist System: Three Unemployment Insurance Approaches in the United States, 2007-2015, 49 J. Soc. PoL'Y 189, 207 (2020). Chang found that less than one-third of states maintained both adequate social protections and sufficient financing, see id., and that the states that provided inadequate social protections "appeared to follow the logic of interstate competition by reducing the benefit level when their benefits were more generous than their neighbouring states," id. at 206.

276. Galle, supra note 274, at 1032; see Wayne Vroman \& Stephen A. Woodbury, Financing Unemployment Insurance, 67 NAT'L TAX J. 253, 265 (2014) (noting that experience rating "creates an incentive for employers to unfairly challenge the UI claims of their former employees, so as to prevent increases in their tax rate"). 
"preventing workers from successfully submitting ongoing weekly claims." 277

Although Congress temporarily expanded unemployment insurance in its stimulus legislation, ${ }^{278}$ these administrative burdens significantly blunted the impact of Congress's action. The Economic Policy Institute estimates that administrative burdens kept between 8.9 and 13.9 million people from filing for unemployment insurance in the immediate wake of the coronavirus pandemic. ${ }^{279}$ And as Professor Galle has explained, "Employers have grown considerably more skilled and aggressive than in the past, resulting in more workers being found ineligible or cut off from benefits before those benefits expire." 280 That development is bound to affect workers who claim unemployment during the pandemic.

The administrative burdens imposed by states were in part inspired by concern about protecting employers against costs in the absence of fault. ${ }^{281}$ They were also inspired by concerns about alleged moral hazard - that if it were too easy for individuals to obtain unemployment benefits, people would have too great an incentive not to return to work. ${ }^{282}$ And some of the eligibility

277. Rachel West et Al., Ctr. For Am. Progress, Strengthening Unemployment Protections in AMERiCA: MODERnizing UnEmPloyment InSURANCE AND Establishing A JOBSEEKER'S ALLOWANCE 68 (2016), https://cdn.americanprogress.org/wpcontent/uploads/2016/05/31134245/UI_JSAreport.pdf [https://perma.cc/9ZAH-F2GZ]; see also Nat'L Emp. L. Project, Are State Unemployment Systems Still Able To Counter RECESSIONS? 4-5 (2019), https://s27147.pcdn.co/wp-content/uploads/Data-Brief-StateUnemployment-Systems-Counter-Recession.pdf [https://perma.cc/6S7Q-PAF3]. Perhaps the most notorious example comes from Michigan, where then-Governor Rick "Snyder slashed the Michigan [Unemployment Insurance Agency] staff by a third and implemented a host of rule changes that made it harder for unemployed workers to get benefits. His initiatives include[d] the now-infamous . . . automated system that levied false charges of fraud against more than 40,000 Michiganders." Nancy Kaffer, Opinion, How Rick Snyder Made It Harder To Collect Unemployment Benefits, DETROIT FREE PRESS (May 15, 2020, 1:52 PM), https://www.freep.com/story/opinion/columnists/nancy-kaffer/2020/05/15/rick-snyder-

michigan-unemployment-fund-uia/5182208002/ [https://perma.cc/FA7V-9NGG].

278. Coronavirus Aid, Relief, and Economic Security (CARES) Act, Pub. L. No. 116-136, $\S \S 2101-16,134$ Stat. 181, 313-35 (2020).

279. Ben Zipperer \& Elise Gould, Unemployment Filing Failures: New Survey Confirms that Millions of Jobless Were Unable To File an Unemployment Insurance Claim, ECON. POL'Y INST. (Apr. 28, 2020, 7:00 AM), https://www.epi.org/blog/unemployment-filing-failures-new-surveyconfirms-that-millions-of-jobless-were-unable-to-file-an-unemployment-insurance-claim/

[https://perma.cc/CL86-CHZD].

280. Galle, supra note 274 , at 1025.

281. See Michael J. Graetz \& Jerry L. Mashaw, True Security: Rethinking American SOCIAL INSURANCE 202 (1999) ("Employer economic incentives, resulting from experience rating, clearly feed back into state coverage policies. Experience rating is therefore implicated in both the current low levels of effective coverage and resistance to relaxing eligibility criteria to qualify workers whose unemployment is not within the employer's control.").

282. See, e.g., Galle, supra note 274 , at 1061. 
rules adopted by states aim directly at that supposed problem. Benefits are generally available only to those who are "able and available" to work and who did not voluntarily leave their previous positions. ${ }^{283}$ Economic evidence suggests that current restrictions on unemployment insurance go well beyond what is necessary to eliminate any inappropriate work disincentive. ${ }^{284}$ Despite that evidence, the able-and-available and voluntary-quit rules remain in place, and they have serious consequences. ${ }^{285}$ Workers who leave jobs for fear of being infected with SARS-CoV-2, or who refuse to take particular jobs because of the same concern, will often be disqualified by these provisions. ${ }^{286}$

These rules thus reinforce the deadly dilemma for people who are especially at risk of COVID-19 infection, work in a position that puts them at risk, or lose any means of providing for basic necessities. Once again, the fault/responsibility paradigm prevents employment law from adequately cushioning the burdens of responding to a public health crisis. As with the rules limiting access to workers' compensation, the rules limiting access to unemployment insurance may in fact be exacerbating employers' moral hazard of shifting costs to workers and society.

283. Lester, supra note 271 , at 352 . On how these rules aim at avoiding workers' moral hazard, see $i d$. at 350-53.

284. See, e.g., Jason Furman, Chairman, Council of Econ. Advisers, The Economic Case for Strengthening Unemployment Insurance 7-8 (July 11, 2016) (transcript available at https://obamawhitehouse.archives.gov/sites/default/files/page/files/20160711_furman_uireform _cea.pdf [https://perma.cc/5HW9-JXKK]) (describing the evidence).

285. Lester, supra note 271, at 352-55.

286. Indeed, a number of public officials have prominently encouraged this result. Iowa Governor Kim Reynolds declared that "[i]f you're an employer and you offer to bring your employee back to work and they decide not to, that's a voluntary quit." Marty Johnson, States Tell Workers They'll Lose Unemployment Benefits if They Refuse To Return to Jobs, HiLL (Apr. 28, 2020, 1:36 PM), https://thehill.com/homenews/state-watch/495050-states-telling-workerstheyll-lose-unemployment-benefits-if-they-refuse [https://perma.cc/WBG6-PSNJ]. Reynolds has urged employers to report to the state those workers who refuse to return. See id. Ohio has encouraged the reporting of employees who do not come back to work when their businesses reopen. See Lauren Aratani, Ohio Urges Employers To Report Workers Fearful of Returning to Work, GUARDIAN (May $8, \quad 2020, \quad 7: 00 \quad$ PM), https:/www.theguardian.com/world/2020/may/08/ohio-coronavirus-reopening-workersunemployment-benefits [https://perma.cc/2B7T-55YC]. The Trump Administration has supported these efforts, on the ground that they will "guard against fraud and abuse" of the unemployment system. Press Release, U.S. Dep't of Lab., U.S. Department of Labor Issues Guidance and Reminders to States To Ensure Integrity of Unemployment Insurance Programs (May 11, 2020), https://www.dol.gov/newsroom/releases/eta/eta20200511-1 [https://perma.cc/8ZVF-F3SS]. 


\section{b. Disability Insurance}

There is a federal program, financed by payroll taxes, for individuals who have left the workforce due to their health conditions-Social Security Disability Insurance (SSDI). SSDI rolls tend to rise during severe economic downturns, a result that might suggest that the program serves as a backup or residual form of unemployment insurance. ${ }^{287}$ If SSDI took up the slack, the limitations of the unemployment insurance program would not be as great a problem.

Unfortunately, SSDI faces its own limitations. For one thing, the Social Security Act provides that workers cannot qualify for the program unless they can demonstrate that they have a severe impairment that makes them unable to perform not only their past work but "any other kind of substantial gainful work which exists in the national economy." 288 The statute erects such a demanding standard because of fears that without a high bar for qualifying as disabled, people who are capable of work will use the program as an excuse for going on the dole. ${ }^{289}$ Indeed, the SSDI program has remained under persistent political threat precisely because of concerns that the statute's bar is not set high enough. ${ }^{290}$ Once again, the fault/responsibility paradigminstantiated as a worry about workers' moral hazard-limits the effectiveness of the law's protection of vulnerable workers.

Many people who are particularly vulnerable to COVID-19 will not satisfy the standard for receiving SSDI benefits. After all, their problem is likely to be a mismatch between their age or medical conditions and the jobs on offer to them rather than an inability to work in any position in the national economy. For those who can satisfy the disability standard, the process can take months or even years ${ }^{291}$ — hardly timely for those who have lost their

287. See Andreas I. Mueller, Jesse Rothstein \& Till M. von Wachter, Unemployment Insurance and Disability Insurance in the Great Recession, 34 J. LAB. ECON. S445, S446 (2016).

288. 42 U.S.C. $\S 423(d)(2)(A)$; see also GRAETZ \& MASHAW, supra note 281, at 72 (stating that "the major determinant of disability claims is . . . the business cycle").

289. See Samuel R. Bagenstos, Disability, Universalism, Social Rights, and Citizenship, 39 CARDOZO L. REV. 413, 421-22 (2017).

290. See id. at 427-28.

291. See, e.g., U.S. Gov't AcCOUnTABILITy OfF., GAO-01-261, Major Management Challenges and Program Risks: Social Security Administration 18 (2001). (“SSA's complex disability claims process has been plagued by a number of long-standing weaknesses that have resulted in lengthy waiting periods for claimants seeking disability benefits. For example, claimants who are dissatisfied with the initial determination and file an appeal frequently wait more than 1 year for a final decision.”). As of May 2019, the average processing time was 520 days for a pending disability claim case. Improve Administration of the Disability Programs, OFF. OF THE INSPECTOR GEN., https://oig.ssa.gov/audits-and-investigations/top-ssamanagement-issues/improve-administration-disability-programs [https://perma.cc/JP39-Q6YD]. 
source of livelihood. SSDI thus cannot be counted on to protect workers against the dilemma of choosing between their lives and their livelihood.

$$
* * *
$$

In all of these respects, legal rules protect employers against costs that we think society ought to bear, but they then turn around and ensure that society won't bear those costs either. Low-wage workers, people of color, women, and people with disabilities are left to fend for themselves. As we showed in Part I, the consequences have been unjust and unequal. The next Part offers some proposed solutions.

\section{Centering Solidarity in PANDEMic PREVEntion ANd Response}

As we have shown, the personal responsibility strategy for mitigating the coronavirus pandemic has been disastrously ineffective. And its benefits and burdens have been allocated in deeply unjust ways. The result has been to exacerbate social fragmentation rather than to foster the solidarity that should drive pandemic response.

In this Part, we sketch the beginnings of an alternative, solidarity-focused approach to pandemic prevention and response. The notion that the health of those at greatest risk-and of the communities with which they are interconnected-is left to the mercy of personal, rather than public, responsibility is antithetical to a solidarity vision of public health. In elaborating our argument, we draw on the theoretical work of public health ethicists and legal scholars who have identified solidarity as a key goal. But our main focus is on concrete legal and policy proposals.

A solidarity approach to pandemic response would support the ability of all people to abide by public health recommendations (and thus to benefit from the pandemic response) and would ensure the burdens of pandemic response are equitably distributed. Supported isolation, quarantine, and social distancing would require securing access to - and eliminating discrimination in-housing, nutrition, education, and health care in the face of social, economic, and cultural disruption. ${ }^{292}$ Our focus here is on employment, where we identify two key areas for reform to ensure more effective and just pandemic prevention and response. First, employment law should protect workers from becoming infected and spreading infection to others. It should

292. See Emily A. Benfer, Seema Mohapatra, Ruqaiijah Yearby \& Lindsay Wiley, Health Justice Strategies To Combat the Pandemic: Eliminating Discrimination, Poverty, and Health Disparities During and After COVID-19, 20 Yale J. HEAlth POL'Y L. \& ETHICs (forthcoming 2021) (on file with authors). 
do so through workplace safety, privacy, and antidiscrimination protections that enable workers to adopt protective health behaviors. And for individuals for whom returning to work would be especially unsafe-whether because their employers maintain particularly dangerous conditions or because of their own, or their family members', underlying health conditionsemployment law should remove any obligation to return to work while the special dangers associated with the pandemic persist.

\section{A. Protect Workers}

Workers who meet our basic needs during a crisis cannot be separated from "the regular people." Essential workers and their household members work, live, learn, and worship in our communities. Protecting them is a moral imperative. It is also a public health imperative. When essential workers become infected-particularly if they don't have access to testing and supported isolation - they may spread infection to their household members and others in their communities. As non-essential businesses and schools have opened up, more and more workers are being asked to put themselves in harm's way.

\section{Safety Precautions}

It is perhaps a banal point, but it deserves emphasis: Just because the individual and societal benefits of working are understood to outweigh the costs, that does not mean that costs are absent. Working during the pandemic - particularly in jobs that require close congregation indoors for long periods of time - poses a high risk of infection. ${ }^{293}$ That is why we have seen so many outbreaks tied to congregate settings like nursing homes, prisons, and meat processing plants. ${ }^{294}$ Those outbreaks eventually pose risks to broader communities, but it is the workers in these settings who face them most acutely.

Solidarity requires that society take steps to protect workers against those risks. These workers are serving society as a whole-through specific "essential" jobs, or through their contribution to the economic life of the community - so society owes it to them to mitigate the harms they face. That obligation has both short-term and long-term components.

293. See Mark Barnes \& Paul E. Sax, Challenges of "Return to Work" in an Ongoing Pandemic, 383 New Eng. J. Med. 779, 780 (2020).

294. See supra text accompanying notes 13-17. 
In the short term, the federal and state governments should require employers to make their workplaces as safe from the risk of SARS-CoV-2 infection as is reasonably possible. This obligation should entail providing personal protective equipment without requiring the workers to pay for it. It also should entail protocols to require employers to act when a coronavirus case is linked to their workplace - including notification of those who might have been exposed and clearing the area in which transmission is likely to have occurred until it can be adequately disinfected. OSHA could impose these obligations as part of an emergency temporary standard ${ }^{295}$ If the agency does not act, Congress should. Congressional action would have the added benefit of potentially socializing the costs of these measures through federal reimbursement of employers who face unusual burdens.

In the long term, the federal government needs to fully fund occupational safety and health enforcement, so that employers can no longer violate the OSH Act with relative impunity. ${ }^{296}$ As a backstop, Congress should give workers a private right of action so that they may sue for violations of the statute when OSHA fails to act. And Congress should add robust whistleblower protections - including their own private right of action- to the Act. During the pandemic, we have seen too many examples of workers who have been fired for calling out risks on the job. ${ }^{297}$ Firings like these send a powerfully threatening message to other potential whistleblowers - one that bolsters employers' impunity for health and safety violations. Currently, though, employees who face retaliation for speaking out about workplace risks are limited to an administrative remedy, one that leaves in the hands of the Department of Labor the decision whether to sue-and one that the worker must invoke within a punishing thirty-day limitations period. ${ }^{298}$

295. See supra text accompanying notes 188-194 (discussing OSHA's refusal, so far, to adopt an emergency temporary standard in response to the pandemic).

296. See supra text accompanying notes 206-208 (discussing OSHA's severe lack of enforcement resources).

297. For just a small sample of stories, see Christine Fisher, US Senators Ask Amazon Why

It Keeps Firing COVID-19 Whistleblowers, ENGADGET (May 7, 2020), https://www.engadget.com/senators-question-amazon-covid-19-whistleblower-firings-

185144658.html [https://perma.cc/7N5M-JKW3]; Ron Judd, Backed by ACLU, Whistleblowing Doctor Sues Bellingham Hospital After He Was Fired for Raising Coronavirus Concerns, SEATTLE TiMES (May 28, 2020, 11:04 AM), https://www.seattletimes.com/seattle-news/aclujoins-ousted-doctor-ming-lin-in-lawsuit-against-bellingham-hospital/ [https://perma.cc/J9EDT38C]; Sarah Rahal, Deaths in Hallways, Unrefrigerated Bodies: Fired Nurses Sue, Cite COVID-19 Conditions at Sinai-Grace, DeTroit News (June 11, 2020, 6:53 PM), https:/www.detroitnews.com/story/news/local/detroit-city/2020/06/11/dmc-sinai-grace-detroithospital-nurses-covid-firing-whistleblowers/5341372002/ [https://perma.cc/94EY-K5HP].

298. See 29 U.S.C. $\S 660(c)$. 
And the pandemic should lead us to rethink the geographic organization of work. Experience born of necessity during stay-home orders has shown that many more jobs can be effectively performed remotely than employers had previously thought. ${ }^{299}$ A post-COVID expansion of work-from-home policies-aided by a significant governmental investment in high-speed internet infrastructure to ensure that historically excluded communities are not left behind ${ }^{300}$ — would help avoid putting workers at needless risk in the next pandemic.

The current crisis has also demonstrated that infectious diseases spread rapidly in congregate residential facilities such as jails, prisons, nursing homes, and psychiatric or developmental disability institutions. ${ }^{301}$ The imperatives to disrupt person-to-person transmission and protect residents and staff from infection should give added weight to longstanding calls for decarceration and deinstitutionalization. ${ }^{302}$ To the extent possible, we should replace these congregate facilities with community-based services and supports that enable people to live in their own homes. Doing so would protect both residents and workers in a future pandemic.

2. Antidiscrimination Rules, Privacy Protections, and Supports for Those Who Should Stay Home

In the previous section, we spoke of the imperative to protect workers generally. We did not draw any distinctions among employees at a given workplace. But workers are not all relevantly the same. Those who are infected by COVID-19 can pose risks to their susceptible coworkers. An employer's obligation to protect susceptible workers may thus require imposing burdens on infected workers. Some susceptible employees may be

299. See, e.g., Olga Khazan, Work from Home Is Here To Stay, ATLAnTiC (May 4, 2020), https:/www.theatlantic.com/health/archive/2020/05/work-from-home-pandemic/611098/

[https://perma.cc/4CPY-TYVF]; Maria Cramer \& Mihir Zaveri, What if You Don't Want To Go Back to the Office?, N.Y. TIMES (May 31, 2020), https:/www.nytimes.com/2020/05/05/business/pandemic-work-from-home-coronavirus.html [https://perma.cc/2H92-AU6U]; Lisa Schur \& Douglas L. Kruse, Coronavirus Could Revolutionize Work Opportunities for People with Disabilities, CONVERSATION (May 5, 2020, 8:18 AM), https://theconversation.com/coronavirus-could-revolutionize-work-opportunities-forpeople-with-disabilities-137462 [https://perma.cc/27G9-NTPE].

300. See Carl Smith, COVID-19 and the Digital Divide, Governing (June 5, 2020), https://www.governing.com/next/Legislative-Watch-COVID-19-and-the-Digital-Divide.html [https://perma.cc/C5SD-CUTN].

301. See supra text accompanying notes 13-17.

302. See generally LIAT BEN-Moshe, DeCARCERATING DisABILITY: Deinstitutionalization And Prison Abolition (2020); Samuel R. Bagenstos, The Past and Future of Deinstitutionalization Litigation, 34 CARDOZO L. REV. 1 (2012). 
older or have chronic conditions that would make them particularly vulnerable to severe illness or death from COVID-19. Some workers don't have those conditions themselves, but they live with people who have them. An employer might wish to exclude these particularly vulnerable employees from the workplace. Or perhaps the employer might have heightened obligations toward them. Either way, different workers will receive different treatment.

Discrimination like this imposes burdens on some workers to protect others. Our solidarity-focused approach demands that the burdens and benefits be distributed fairly across these groups. There are three key questions here: When may an employer exclude a worker for posing a risk to others? What techniques may an employer use to determine which workers to exclude? And what is the employer's - or society's - obligation to those workers who must, or appropriately choose to, stay home? As we consider these questions, we keep in mind the lessons of the HIV pandemic, in which legal protections for privacy and against discrimination have been key tools for supporting public health measures. ${ }^{303}$ Testing saves lives. Not necessarily the lives of people who are tested, but the lives of people they might be able to avoid infecting if they know their status. From the HIV experience, we know that telling people to get tested isn't enough. ${ }^{304}$ Testing also has to be accessible, and people who get tested have to be confident they won't face serious social or economic repercussions if the test result is positive. ${ }^{305}$

\section{a. When May an Employer Exclude a Worker?}

The ADA specifically permits employers to exclude workers who, because of their disabilities, "pose a direct threat to the health or safety of other individuals in the workplace." "306 With the Supreme Court's blessing, the EEOC has extended that "direct threat" defense to cases in which a worker's employment will pose a significant risk to the worker him- or herself. ${ }^{307}$ But the law sharply limits an employer's discretion to exclude a worker based on a direct threat. The statute and the regulations define "direct threat" as a "significant risk" to health or safety "that cannot be eliminated

303. See Burris, supra note 41 , at 855.

304. See John E. Anderson et al., HIV Antibody Testing and Posttest Counseling in the United States: Data from the 1989 National Health Interview Survey, 82 AM. J. PuB. HEALTH 1533, 1534 (1992) (estimating that less than half of those at high risk for contracting AIDS were tested).

305. See Burris, supra note 41, at 835-36 (arguing that individual rights to privacy and nondiscrimination in employment, housing, and public accommodations support HIV prevention goals).

306. 42 U.S.C. $\S 12113($ b).

307. See 29 C.F.R. $§ 1630.2(r)$ (2019); Chevron U.S.A., Inc. v. Echazabal, 536 U.S. 73, 76 (2002). 
by reasonable accommodation." ${ }^{308}$ The regulations and the case law require that any direct-threat determination must "be based on an individualized assessment of the individual's present ability to safely perform the essential functions of the job," which assessment itself must "be based on a reasonable medical judgment that relies on the most current medical knowledge and/or on the best available objective evidence." ${ }^{309}$ In making that determination, the Supreme Court has said "the views of public health authorities, such as the U.S. Public Health Service, CDC, and the National Institutes of Health, are of special weight and authority." 310

At least insofar as these rules permit employers to exclude workers who pose significant risks to others, ${ }^{311}$ the "direct threat" doctrine under the ADA largely comports with our solidarity approach. Solidarity requires protecting workers against others who will likely harm them (so long as reciprocal supports are provided to the workers who are excluded, as we discuss below). Because employers may be driven by bias or conflicts of interest, it is appropriate that they should be stringently regulated in making exclusion decisions and, where possible, guided by the recommendations of public health authorities regarding the period of infectiousness. ${ }^{312}$ And where effective vaccines and treatments for a dangerous disease are not widely available, as is currently the case for COVID-19, those who are infectious would almost certainly pose a significant risk. ${ }^{313}$

\section{b. How May an Employer Identify Which Workers To Exclude?}

This question raises more complex issues. The only way an employer can reliably identify which workers pose a risk of transmission is to require medical examinations or tests. But individuals have significant interests in

308. 42 U.S.C. § 12111(3); see 29 C.F.R. § 1630.2(r) (2019) (defining "direct threat" as "a significant risk of substantial harm to the health or safety of the individual or others that cannot be eliminated or reduced by reasonable accommodation").

309. 29 C.F.R. $§ 1630.2(r)$; see Chevron, 536 U.S. at $85-86$.

310. Bragdon v. Abbott, 524 U.S. 624, 650 (1998).

311. For a critique of Chevron's extension of the direct threat defense to include threats to self, see Samuel R. Bagenstos, The Supreme Court, the Americans with Disabilities Act, and Rational Discrimination, 55 ALA. L. REV. 923 (2004).

312. For a defense of the ADA's deference to public health authorities in the direct threat doctrine, see Bagenstos, supra note 187, at 1492-1503.

313. The EEOC has stated as much. See What You Should Know About COVID-19 and the $A D A$, the Rehabilitation Act, and Other EEO Laws, U.S. EQUAL EMP. OPPORTUNITY COMM'N, https://www.eeoc.gov/wysk/what-you-should-know-about-covid-19-and-ada-rehabilitation-actand-other-eeo-laws [https://perma.cc/P8BR-4TWQ] ("An employer may exclude those with COVID-19 . . f from the workplace because, as EEOC has stated, their presence would pose a direct threat to the health or safety of others.") (Sept. 8, 2020). 
keeping their health information private from their bosses. ${ }^{314}$ Solidarity requires accommodating those privacy interests with the health interests of coworkers, vendors, customers, and the communities in which they live.

Once again, the ADA offers a framework consistent with our solidarity approach. The statute prohibits employers from requiring incumbent employees to submit to medical examinations or disability-based inquiries "unless such examination or inquiry is shown to be job-related and consistent with business necessity." 315 EEOC regulations implementing the statute require that any information obtained in such examinations "shall be collected and maintained on separate forms and in separate medical files and be treated as a confidential medical record," with three narrow exceptions: where a supervisor needs to know of necessary work restrictions or accommodations, where it is "appropriate" for first responders to know of an employee's disability that "might require emergency treatment," or where government investigators ask for the information. ${ }^{316}$

Given the current risks attendant to SARS-CoV-2 infection, an employer could appropriately require periodic tests of its employees pursuant to these provisions. ${ }^{317}$ It could also appropriately require workers to disclose their exposure to people with known infection. ${ }^{318}$ So long as the employer keeps the information confidential — and so long as workers who test positive or disclose their potential exposure are provided workplace accommodations or out-of-work supports - such practices are consistent with solidarity. A worker has obligations to others in society, just as society has correlative obligations to the worker.

To recognize that an employer may require testing for its employees raises additional questions, though. What, beyond excluding infected employees

314. For a normative defense of worker privacy protections, see Bagenstos, supra note 55, at 247-53.

315. 42 U.S.C. $\S 12112(\mathrm{~d})(4)(\mathrm{A})$.

316. 29 C.F.R. $\S 1630.14$ (c) (2019).

317. The EEOC has issued guidance stating that an employer may lawfully "administer COVID-19 testing to employees before initially permitting them to enter the workplace and/or periodically to determine if their presence in the workplace poses a direct threat to others," so long as the employer "ensure[s] that the tests are considered accurate and reliable." U.S. EQUAL EMP. OPPORTUNITY COMM’N, supra note 313.

318. On its face, the Genetic Information Nondiscrimination Act appears to prohibit an employer from requesting information about "the manifestation of a disease or disorder in family members." See 42 U.S.C. $\S \S 2000 \mathrm{ff}(4)(A)(i i i), 2000 \mathrm{ff}-1$ (a)(1). Courts have read this provision as limited to cases in which the requested information involves diseases with a genetic or hereditary component. See, e.g., Poore v. Peterbilt of Bristol, L.L.C., 852 F. Supp. 2d 727, 731 (W.D. Va. 2012). For a critique of Poore, which nonetheless agrees that the statute does not cover spousal health information, see Mark A. Rothstein, Jessica Roberts \& Tee L. Guidotti, Limiting Occupational Medical Evaluations Under the Americans with Disabilities Act and the Genetic Information Nondiscrimination Act, 41 AM. J.L. \& MED. 523, 557 (2015). 
from the workplace during the period in which they may transmit the disease, may an employer do with the information disclosing that a worker has been infected? The EEOC has said that it is consistent with general medical confidentiality to report that information to public health authorities for appropriate follow-up. ${ }^{319}$ Whether the employer may conduct its own contact tracing within the workplace (beyond obvious steps like identifying and informing anyone who works in the same location as an affected employee) raises more difficult questions. Businesses are likely to have less expertise in contact tracing than are public health authorities and the outside entities they engage to perform that work. Workers may reasonably fear that disclosures of contacts to company officials will not remain private or will be used for purposes that go beyond protecting their coworkers' health. And because everyone has contacts with people both in and out of the workplace, employer-conducted tracing efforts will necessarily overlap with (and thus duplicate) the work that public health authorities and allied organizations are already doing. It may thus make the most sense to leave contact tracing in the hands of those authorities. Individuals who test positive for infection should be required to cooperate with an appropriate contact tracing regime, however.

What about "immunity passports"? 320 May an employer demand that workers demonstrate immunity from a deadly infectious disease, by providing either a positive antibody test or (when it becomes available) proof of vaccination? Under the ADA at the moment, the answer is clear enough. Although FDA has authorized COVID-19 vaccines for emergency use, they are not yet widely available and manufacturers have not yet sought full FDA approval through biologics license applications. ${ }^{321}$ Though antibody tests are available, they vary in their reliability — and it is not yet clear whether prior infection confers future immunity, and if so, how strong or long-lasting that

319. U.S. EQUAL EMP. OPPORTUNITY COMM'N, supra note 313 (stating that an employer may "disclose the name of an employee to a public health agency when it learns that the employee has COVID-19").

320. For a general discussion of the issues entailed by immunity passports, see Alexandra L. Phelan, COVID-19 Immunity Passports and Vaccination Certificates: Scientific, Equitable, and Legal Challenges, 395 LANCET 1595 (2020).

321. Press Release, U.S. Food \& Drug Admin., FDA Takes Additional Action in Fight Against COVID-19 by Issuing Emergency Use Authorization for Second COVID-19 Vaccine (Dec. 18, 2020), https://www.fda.gov/news-events/press-announcements/fda-takes-additionalaction-fight-against-covid-19-issuing-emergency-use-authorization-second-covid

[https://perma.cc/33AN-FSWC]; Kayla Rivas, Pfizer To Request COVID-19 Vaccine Full Approval in 'First Half of 2021,' FOX NEws, https://www.foxnews.com/health/pfizer-requestfull-approval-coronavirus-vaccine-first-half-2021-fda [https://perma.cc/RT5C-NCAK]. 
immunity will be. ${ }^{322}$ Under these circumstances, the EEOC has determined that antibody testing is not "job related and consistent with business necessity" and is thus barred by the ADA. ${ }^{323}$

At some point, however, vaccines will become more widely available and we may eventually develop a reliable test of acquired immunity. At that point, the business-necessity calculus will change. Lack of immunity does not present the same risk of transmission as an active infection. But workers in high-risk settings - especially nursing home staff, home health workers, and others whose work requires close contact with people who are particularly vulnerable to COVID-19 - may be subject to vaccination requirements as a condition of employment. This requirement could come from state and local governments or from employers themselves. Annual vaccination of healthcare workers for seasonal flu has been recommended - but not required - by the CDC for decades. ${ }^{324}$ Some states require it, and many require at least some vaccinations for at least some health workers. ${ }^{325}$ These requirements are already controversial. ${ }^{326} \mathrm{We}$ expect any requirement to accept a new vaccine that the Trump administration has touted as being developed at "warp speed" to be even more so. ${ }^{327}$ For some, particularly Black Americans, vaccine

322. Robert H. Shmerling, Which Test Is Best for COVID-19?, HaRV. HeAlTh PuBL'G: HARV. HeALTH BloG (Jan. 5, 2021, 5:34 AM), https://www.health.harvard.edu/blog/which-testis-best-for-covid-19-2020081020734 [https://perma.cc/YZ8B-QR2X].

323. U.S. EQUAL EMP. OPPORTUNITY COMM'N, supra note 313.

324. See, e.g., Vaccine Information for Adults: Healthcare Workers, CTRS. FOR DISEASE CONTROL \& PREVENTION, https://www.cdc.gov/vaccines/adults/rec-vac/hcw.html [https://perma.cc/TV8Y-JYMU] (May 2, 2016).

325. See State Immunization Laws for Healthcare Workers and Patients, CTRS. FOR DISEASE CONTROL \&

PREVENTION, https://www2a.cdc.gov/vaccines/statevaccsApp/AdministrationbyVaccine.asp?Vaccinetmp=Infl uenza [https://perma.cc/DZB8-KUU9].

326. See, e.g., Maggie Fox, They Didn't Get Vaccinated. Now They're Out of Jobs, NBC NEws (Nov. 22, 2017, 2:49 PM), https://www.nbcnews.com/health/health-news/they-didn-t-getvaccinated-now-they-re-out-jobs-n823446 [https://perma.cc/CRR5-RBN3] (describing "a growing trend for hospitals to require flu shots for workers," accommodations offered by some hospitals, and controversy surrounding the policies).

327. See, e.g., Jan Hoffman, Mistrust of a Coronavirus Vaccine Could Imperil Widespread Immunity, N.Y. TIMES (Sept. 1, 2020), https://www.nytimes.com/2020/07/18/health/coronavirusanti-vaccine.html [https://perma.cc/A4EN-8N4Y]; Kashmira Gander, Third of Americans Say They Won't Get a COVID-19 Vaccine, with Black Americans the Most Skeptical, NEWSWEEK (June 10, 2020, 10:32 AM), https://www.newsweek.com/american-covid-19-vaccine-skeptical1509895 [https://perma.cc/AXJ2-2ZJK]. 
hesitancy may be shaped by distrust fostered by a long history of racism and unethical treatment at the hands of the public health establishment. ${ }^{328}$

Before employers or public health authorities mandate vaccination, there must be a credible, public demonstration of the efficacy, and the risk-benefit balance, of a vaccine. Even then, the disability discrimination laws may require accommodations for some workers for whom vaccination is unsafe. The option of presenting an antibody test result could be one such accommodation, depending on whether such results are eventually deemed reliable. If reasonable accommodations are made, acceptance of vaccination as a condition of working in a setting that poses a high risk of transmission to others is part of what each of us owes our fellow members of the workplace and community.

Absent a vaccine, a requirement of immunity passports would be much more problematic. If the only way to acquire immunity without a vaccine is to become infected with COVID-19 (or possibly with a similar virus), people will have a strong incentive to expose themselves to the virus so that they can receive the passport and go back to work. ${ }^{329}$ That could have the perverse effect of increasing the spread of infection. It will once again present a deadly dilemma to those who, due to chronic conditions, face especially serious harm if they get infected; run the risk of that harm in the hope of acquiring immunity; or give up opportunities to earn a living. That dilemma will

328. See Olivia Lewis, Black, Hispanic Detroiters Hesitant To Take Coronavirus Vaccine, BRIDGEDETROIT (Dec. 3, 2020), https://www.bridgedetroit.com/black-hispanic-detroitershesitant-to-take-coronavirus-vaccine/ [https://perma.cc/WN5Q-Z2FP]. One study found

[t]he clearest racial divide [among focus group participants] in vaccine confidence was between White and African American participants' different levels of trust in the government's role in vaccination. White participants expressed greater trust in government, while African American participants voiced lower trust, with particular concerns regarding the government's motives. . . This distrust extended into conspiracy theories including beliefs that the government was experimenting on minorities as 'guinea pigs', that the vaccines were being diluted and distributed in Black communities, or that vaccines were a form of population control. Additionally, the legacy of the Tuskegee Syphilis Study emerged in every focus group as a justification for distrust.

Sandra Quinn, Amelia Jamison, Donald Musa, Karen Hilyard \& Vicki Freimuth, Exploring the Continuum of Vaccine Hesitancy Between African American and White Adults: Results of a Qualitative Study, PLOS CURRENTS OUTBREAKS (Dec. 29, 2016) (emphasis omitted), https://currents.plos.org/outbreaks/article/exploring-the-continuum-of-vaccine-hesitancybetween-african-american-and-white-adults-results-of-a-qualitative-study/

[https://perma.cc/8KEW-X33V].

329. Daniel Hemel \& Anup Malani, Immunity Passports and Moral Hazard 3 (U. Chi. Pub. L., Working Paper No. 743, 2020), https://papers.ssrn.com/sol3/papers.cfm?abstract_id=3596569 [https://perma.cc/HB9L-H8BE]. 
necessarily fall more heavily on disabled individuals as well as "[c]ommunities of color, including Black, Latinx, and Indigenous communities," who "already face health disparities due to socioeconomic barriers." ${ }^{330}$ These considerations weigh against generally allowing employers to rely on immunity passports, at least in the absence of a safe, effective, and widely available vaccine.

What if a worker refuses to submit to legitimate workplace testing or, absent a valid health excuse, refuses to be vaccinated? So long as those who are infectious or are at especial risk receive appropriate support outside of the workplace, we believe that employers should be permitted to exclude such workers. To allow a worker to impose risks on others, without a sufficient reason, is antithetical to the burden-sharing that is the essence of solidarity. It is crucial piece of the bargain, however, that employers and the government provide adequate support to those who cannot or should not work. That is the issue to which we now turn.

\section{c. What Is the Employer's and the Government's Obligation to Workers Who Must or Should Stay Home?}

As we have said, solidarity requires that some people stay home from work when they are possibly infectious so that they do not impose risks on others. Others should have the option to stay home because they are older or have chronic conditions that will place them at high risk of serious harm if they contract the virus. And still others should have the option to stay home because they have caregiving obligations - to children whose schools are closed by the pandemic, to family members who have themselves been infected, et cetera. Solidarity imposes on society a correlative obligation to cushion the blow for those individuals, who are sacrificing for the good of other members of the community.

Where the need to stay home lasts for a relatively short amount of time, job accommodations are an obvious response. If a person tests positive for COVID-19, for example, but is not too sick to work, the employer should endeavor to restructure their job or temporarily reassign them to a new position that can be performed remotely. That accommodation should continue until the worker is no longer infectious. Accommodations like these are generally required by the ADA in any event. ${ }^{331}$

Accommodations like these should also be the first option for those who are older or who have chronic conditions that make them particularly

330. Esha Bhandari \& ReNika Moore, Coronavirus 'Immunity Passports' Are Not the Answer, ACLU (May 18, 2020), https:/www.aclu.org/news/privacy-technology/coronavirusimmunity-passports-are-not-the-answer/ [https://perma.cc/VV5T-EAGP].

331. See 42 U.S.C. $§ 12111(9)(B)$. 
vulnerable to COVID-19. If the workplace remains unsafe for an individual with such a condition for a sufficiently long time, however, the accommodation will likely become an "undue hardship." 332

At that point, the accommodation will no longer be required by the ADA. It would also be unfair to demand that the employer alone bear such a heavy burden simply due to the fortuity that it happened to hire a worker with a preexisting health condition. ${ }^{333}$ And imposing that burden would give employers an incentive to discriminate in hiring against workers with such conditions. Where longer-term accommodations are required, then, the federal government should socialize the costs for workers to take paid leaves of absence. For the same reasons, workers who are too sick to work or who have caretaking responsibilities should receive paid leave financed by a similar program. And workers who are fired after refusing to report for assignments that present special risks to them should no longer be deemed to have "voluntarily" quit or to be not "available" for work in ways that disqualify them from unemployment insurance. ${ }^{334}$ People should be supported in staying home in these circumstances, and the cost should be shared across society.

The solidarity approach would justify a broader array of universal workplace protections that would extend beyond just the COVID-19 pandemic - or, indeed, any pandemic. Even outside of a pandemic situation, guaranteed paid family care, medical, and sick leave would serve solidarity interests. Our argument thus supports the longstanding proposals for a federally funded paid leave program. ${ }^{335}$ And although the current pandemic puts the pathologies of our current unemployment insurance system in particularly bold relief, we cannot solve those pathologies by a narrow reform limited to the current crisis. Rather, we should take the long-overdue step of

332. See id. § 12112(b)(5)(A).

333. For an argument that the obligation to avoid contributing to a system of societal subordination justifies requiring the employer to pay for "reasonable" accommodations that do not work "undue hardship" — an argument that readily translates to this context — see Samuel R. Bagenstos, "Rational Discrimination," Accommodation, and the Politics of (Disability) Civil Rights, 89 VA. L. REV. 825, 869-70 (2003).

334. Some, but far from all, states allow workers to receive unemployment in these circumstances. See, e.g., Kathleen Pender, Californians Who Refuse Work Because of Coronavirus May Still Get Unemployment Benefits, S.F. CHron. (May 13, 2020, 6:39 PM) https://www.sfchronicle.com/business/networth/article/Californians-can-refuse-some-workduring-15267447.php [https://perma.cc/X37Y-5QAL].

335. See, e.g., Gillian Lester, A Defense of Paid Family Leave, 28 HARV. J.L. \& GENDER 1 (2005); see also Catherine Albiston \& Lindsey Trimble O’Connor, Just Leave, 39 HARV. J.L. \& GENDER 1, 50 (2016) ("On the surface, paid family leave programs seem to solve work-family conflict, but for some workers, especially those in precarious jobs, the choice to take paid family leave may not be viable without broader legal protections."). 
moving the unemployment insurance system to the federal government, so that benefit levels are not subject to the interstate race to the bottom. ${ }^{336}$

\section{CONCLUSION}

The coronavirus pandemic has been a test of our ability to respond to the profound insights of social epidemiology. People's health-related behaviors - and the ways in which they encounter the agents of communicable disease - are shaped by their social, economic, and employment circumstances. Telling people to take personal responsibility for avoiding infection without creating the conditions required for them to be able to do so does not work. ${ }^{337}$ Moreover, it further exacerbates health disparities and fragments our society. The personal responsibility ethos that has driven the U.S. pandemic response has been ineffective, atomizing, and unjust.

Interventions that place the onus on individuals to change their behavior have been woefully inadequate to achieve community mitigation. Congress, the federal administration, and governors have taken people's socioeconomic circumstances as a given, instead of adopting a community-responsibility frame to address them directly through job protections and income support. The results have been predictably disastrous. As Professor Daniel Goldberg has said in response to the critique of new public health, "either the social epidemiologists' contention that socioeconomic disparities are a primary factor in causing good public health is accurate, or it is not." 338

The COVID-19 pandemic has given us an answer. It doesn't work to tell people to change their behaviors - to stay home and keep their distance from others when out and about - without changing the context so they can follow public health recommendations without facing existential threats to their employment and basic income. It doesn't work to expect people to report for duty in high-risk settings - factories, nursing homes, bars, restaurants, classrooms - while putting the onus on them to provide their own personal

336. For previous proposals to federalize unemployment insurance, see STEPHEN A. WANDNER, W.E. UPJOHN INST. FOR EMP. RSCH., OPTIONS FOR UNEMPLOYMENT INSURANCE Structural AND AdMinistrative Reform: Proposals AND AnAlysis (2020), https://research.upjohn.org/cgi/viewcontent.cgi?article=1019\&context=up_policypapers [https://perma.cc/GHT3-VS73].

337. $C f$. Richard Wilson \& Kate Pickett, The Spirit LeVel: Why Greater Equality MAKES SOCIETIES STRONGER 234 (2010) ("[I]nitiatives aimed at tackling health or social problems . . . often seem to be based on the belief that the poor need to be taught to be more sensible. The glaringly obvious fact that these problems have common roots in inequality and relative deprivation disappears from view.").

338. Goldberg, supra note 48 , at 73 . 
protective equipment and try to find a way to perform their job duties while maintaining physical distance. Telling schoolteachers and students they can pop outside to get some fresh air during scheduled breaks doesn't cut it. As Goldberg argues, "[I]f socioeconomic disparities are truly productive of public health, policies consistent with the narrow model, which by definition do nothing to ameliorate social conditions, will do little to actually improve health in the aggregate." ${ }^{339}$ And that is exactly the world we are living in right now.

Moreover, attention to the factors that expose low-wage workers, people with disabilities, immigrants, Black people, Indigenous people, Latinos, and Latinas to greater health risks - infectious diseases and the chronic conditions that have made them more vulnerable to COVID-19- cannot be reserved for times of crisis. As Tong reflected following her pandemic planning experience, "[W]hy is it that society creates task forces to meet all people's, but especially vulnerable people's, needs during [a] pandemic or . . . natural disaster, when that same society ignores and/or neglects meeting vulnerable people's needs in relatively good times?" 340 Though moments of crisis create the desire to come to each other's mutual aid, that motivation is impotent if it doesn't lead to action. Mutual aid efforts within communities have been powerful but limited in their reach. Employment and antidiscrimination law reforms grounded in solidarity are overdue.

"[T]aking solidarity seriously," as Professors Angus Dawson and Bruce Jennings have urged public health ethics must, "allows us to see ... the distribution of health and disease as being of joint and common concern." ${ }^{341}$ The coronavirus pandemic has demonstrated the deeply interdependent nature of individual and public health. But thus far, the U.S. response has further atomized our society rather than fostered deeper connections between individuals and their communities. This crisis may be a preview of even more existential threats to come within a generation. As with COVID-19 (which is caused by a zoonotic virus sensitive to environmental changes) $)^{342}$, "health threats associated with climate change are likely to exacerbate underlying health disparities," particularly for "the poor, city-dwellers, the elderly, and

339. Id. at 75 .

340. Tong, supra note 110, at 226.

341. Dawson \& Jennings, supra note 9, at 77.

342. John S. Mackenzie \& David W. Smith, COVID-19-A Novel Zoonotic Disease: A Review of the Disease, the Virus, and Public Health Measures, 32 Asia PAC. J. PuB. HeAlth 145, 146 (2020); Sindy SanJuan-Reyes et al., COVID-19 in the Environment, CHEMOSPHERE, Aug. 14, 2020 , at 6 . 
those who suffer from chronic health conditions." ${ }^{343}$ Like the coronavirus pandemic, "climate change adaptation will raise issues of health equity and put pressure on the traditional divide between public and private responsibility for health." ${ }^{344}$ Centering solidarity—including in employment and antidiscrimination law - to respond to this pandemic may help build social resilience to cope with future threats. By contrast, treating pandemic prevention and response as a matter of personal responsibility could leave our society fragmented and ill prepared for future crises.

The new public health law-built on a social-ecological model that elucidates how people interact with each other and the agents of disease and injury within social, economic, and physical environments - is not only tenable but essential. Addressing the social determinants of health does not put the coherence of public health law as a field at risk. Concerns about politicizing public health law by eroding its supposed scientific neutrality miss the fact that public health law is unavoidably political. ${ }^{345}$ "Public health has always been politically controversial. And public health law-which concerns the extent of government authority to intervene to protect the public's health-lives in the thick of this controversy." 346 Our collaboration demonstrates the power of placing public health principles at the center of legal frameworks that govern "non-health" sectors and placing social solidarity at the center of public health.

The deeply unjust distribution of the burdens and benefits of our response to the coronavirus pandemic is no accident. It is shaped by social and economic policies that have determined the health and wellbeing of individuals and communities for generations. Our laws-including public health, employment, and antidiscrimination laws - center personal responsibility and blame in ways that contribute to and exacerbate economic injustice and structural racism rather than prevent and ameliorate harm. Law itself is a social determinant of health and wellbeing. It has brought us where we are today and, for better or worse, it will take us where we're going next.

343. Lindsay F. Wiley, Adaptation to the Health Consequences of Climate Change as a Potential Influence on Public Health Law and Policy: From Preparedness to Resilience, 15 WIDENER L. REV. 483, 486 (2010).

344. Id.

345. Daniel S. Goldberg, Against the Very Idea of the Politicization of Public Health Policy, 102 AM. J. PUB. HeAlth 44, 44 (2012).

346. GosTIN \& WILEY, supra note 28 , at 532. 